\title{
What Drives the Stock Market Comovements between Korea and China, Japan and the US?
}

\author{
Jinsoo Lee*, Bok-Keun Yu**
}

The views expressed herein are those of the authors and do not necessarily reflect the official views of the Bank of Korea. When reporting or citing this paper, the authors' names should always be explicitly stated.

* Associate Professor, KDI School of Public Policy and Management, Tel: +82-44-550-1060, E-mail: jlee@kdischool.ac.kr

** Senior Economist, Micro \& Institutional Economics Team, Economic Research Institute, The Bank of Korea, Tel: +82-2-759-5461, E-mail: bokyu@bok.or.kr.

The authors are grateful to Dr. Wook Sohn, Dr. Hwan-Koo Kang and Dr. Hyunjoon Lim at the Bank of Korea, Prof. Sangwon Suh at Chung-Ang University, an anonymous reviewer, and the participants at the interim seminar and BOJ-BOK Research Workshop for their valuable comments and suggestions. 


\section{Contents}

I . Introduction …………………………………………………… 1

II. Trade and Stock Market Trends in Korea …………….. 3

III. Literature Review …………………………………………... 7

IV. Data and Methodology ………………………………….... 10

V. Empirical Results ……………………………………....... 17

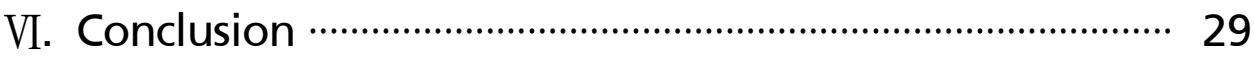

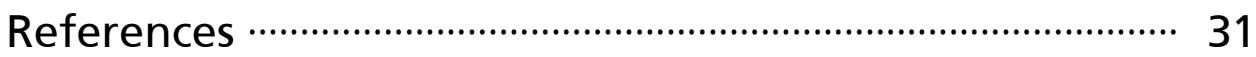




\section{What Drives the Stock Market Comovements between Korea and China, Japan and the US?}

This paper measures the extent of comovements in stock returns between Korea and three major countries (China, Japan and the US) using the industry-level data for Korea from 2003 to 2016, in the spirit of the international capital asset pricing model. It also examines what drives the comovements between Korea and the three countries.

We find that the comovements of the Korean stock returns with those of the US and Japan became smaller after the global financial crisis. In contrast, the comovement in stock returns between Korea and China became larger after the crisis. After an additional analysis, we conclude that trade linkage is the main driver of the comovements between Korea and the three countries.

Our finding suggests that the concentration of trade with some trading partners can be a destabilizing factor in the domestic financial market if there is a negative shock to trade with those partners. Thus, it is important for Korea to diversify trade with foreign countries to keep its financial market more stable.

Keywords: Stock market comovement, Trade linkage, Financial linkage

JEL Classification Numbers: F15, F21, G15 


\section{I . Introduction}

The Korean stock market has shown a high degree of comovement with major countries' stock markets, which may reflect increasing real linkage as well as more financial integration with those countries. It is also intriguing that the extent of comovement has been changing over time and the degree of change seems to be different for different countries. For example, comparing the period before the global financial crisis with the post-crisis period, the correlations of Korean stock market returns with those of China and the US rose, but the stock market comovement between Korea and Japan decreased.1) In this paper, motivated by these observations, we examine what drives the stock market comovements between Korea and three major countries (China, Japan and the US).

To address this issue, we first measure the comovements in stock returns between 24 Korean manufacturing industries and the three countries using a model in the spirit of the international capital asset pricing model (ICAPM), where the expected return of a country's stock market is influenced by global stock market returns. Specifically, we use the market returns of the three major countries as proxies for global stock market returns, and the stock returns for Korean manufacturing industries are related to the market returns of the three countries. In our model, the degrees of the comovements between Korean manufacturing industries and the three countries are measured by slope coefficients (betas) of the three countries for those industries.

Next, we examine the driver(s) of the comovements between Korean manufacturing industries and the three countries. According to conventional financial theory, the price of a security can be modelled as the present value of future cash flows from the security, with the future cash flows being discounted at appropriate discount rates. If this is the case, the degree of commonality between securities may come from two sources: (i)

1) The correlation coefficients of Korea-China, Korea-Japan and Korea-US stock market returns using weekly data from Datastream were $0.49,0.59$ and 0.47 , respectively, for the period of 2003-2007. However, the coefficients changed to $0.69,0.49$ and 0.60 , respectively, for the period of 2010-2016. 
comovement in cash flows (real linkage) and (ii) comovement in discount rates (financial linkage). In this paper, as proxies for the two sources of comovement, we use the ratio of trade to sales for real linkage and the share of foreign stock investment for financial linkage.

From our analysis, we find that the comovements of the Korean stock market with those of the US and Japan became smaller after the global financial crisis. In contrast, the post-crisis comovement in stock returns between Korea and China is larger than that of the pre-crisis period. With the two proxies for real and financial linkages, we find that the trade to sales ratio is positively related to the degree of comovements in stock returns between Korea and the three countries. On the other hand, we find no evidence that financial linkage proxied by foreign stock investment is related to comovements in stock returns between Korea and the three countries.

There are previous studies such as Forbes and Chinn (2004), Elekdag et al. (2012) and Arslanalp et al. (2016) where a two-stage factor model like ours is employed in order to study the linkage in financial markets across countries. These studies use aggregate and macro-level data for sample countries and thus variations in the linkages and its determinants at the country level. In contrast, our study uses industry-level data for an individual country, i.e. Korea. As there are cross-sectional variations as well as time-series variations across industries, we can use such variations in order to examine the issue for an individual country in more depth with industry-level data. In this regard, we expect that our study at the industry level for an individual country will complement previous studies at the country level for groups of countries.

The rest of the paper is organized as follows. In Section II, we explain trade and stock market trends in Korea. We provide a review of the literature in Section III. In Section IV, we describe the data and introduce the methodology for our analysis. We report the empirical results of our analysis in Section V. We conclude in Section VI. 


\section{Trade and Stock Market Trends in Korea}

Korea's trade (exports plus imports) seems to reflect the overall conditions of the global economy as well as its evolvement. Figure 1 shows the shares of exports, imports and trade in Korea's GDP from 2003 to 2016. The trade share continued to rise until 2008, mainly on the back of a favorable global economy. However, it declined sharply in 2009 in the aftermath of the global financial crisis. From 2010, it again increased and recorded 96\%, the highest ratio, in 2011. It has been falling since 2012, which may be attributed to sluggish investment due to delayed global economic recovery from the crisis. The share of trade in GDP was $65 \%$ as of 2016, similar to the level in 2007.

Both exports and imports show similar trends. In 2016, the share of exports and imports in GDP accounted for $37 \%$ and $28 \%$, respectively. As shown in Figure 1, trade surplus (exports - imports) has increased after the crisis, which is mainly due to a decrease in commodity prices and strong exports of Korea's flagship products such as semiconductors and automobiles.

Figure 1. Shares of Exports, Imports and Trade in Korea's GDP

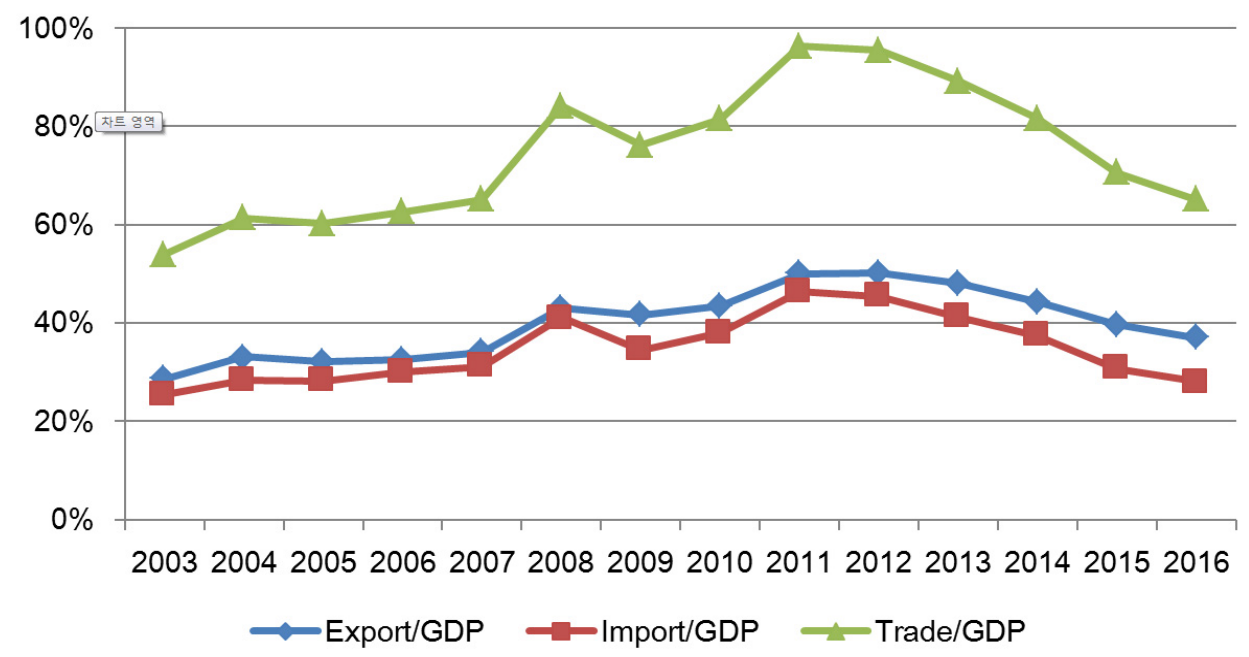

Note: Data are based on nominal amount, goods and Korean won standards.

Source: Bank of Korea (ECOS) 
Figure 2 shows the shares of exports, imports and trade with three major trading partners of Korea (the US, Japan and China) for the period from 2003 to 2016. In the case of the US, the shares of exports and imports continued to decline until 2011. The uptrend in recent years is presumably due to the Korea-US FTA, which came into effect on March 15, 2012. For Japan, both the export and import shares showed declining trends throughout the period. As of 2016, the share of imports was $11.7 \%$, whereas the share of exports was $4.9 \%$. In the case of China, in contrast to the US and Japan, the shares of exports and imports have increasing trends. The shares of exports and imports were $25.1 \%$ and $21.4 \%$ in 2016 , which accounted for the largest portion among Korea's trade partners. Consequently, the share of China in Korea's trade is much higher than those of the US and Japan and recorded 23.4\% in 2016. This indicates that China may become a more dominant player in Korea's trade dynamics and thus may have a bigger impact on the Korean economy than before, both in real and financial aspects.

The Korean stock market has continued to advance together with the growth of its real economy. Figure 3 represents the ratio of market capitalization to GDP and foreigners' share of stock market capitalization in Korea. The ratio of market capitalization to GDP rose from $48 \%$ in 2003 to $101 \%$ in 2007 . During the crisis, the ratio plunged to $56 \%$ in 2008. The ratio then resumed its increase before holding steady at around $90 \%$. On the other hand, foreigners' share of stock market capitalization in Korea reached around 40\% in 2003 and 2004, and then declined gradually to $27 \%$ in 2008. Afterwards, it increased, reaching $32 \%$ in 2016 , but it still remains lower than in 2003.

Figure 4 reports the share of foreign investors from the US, Japan and China. As of 2016, the US accounted for 49\%, whereas the shares of Japan and China were only $3 \%$ and less than $1 \%$, respectively. The US portion has been much larger than those of Japan and China throughout the entire period. This implies that the influence of US investors on Korean stock market may be more evident than those of the other two countries. 
Figure 2. Shares of Korea's Exports, Imports and Trade with the US, Japan and China

[Panel A: Exports]

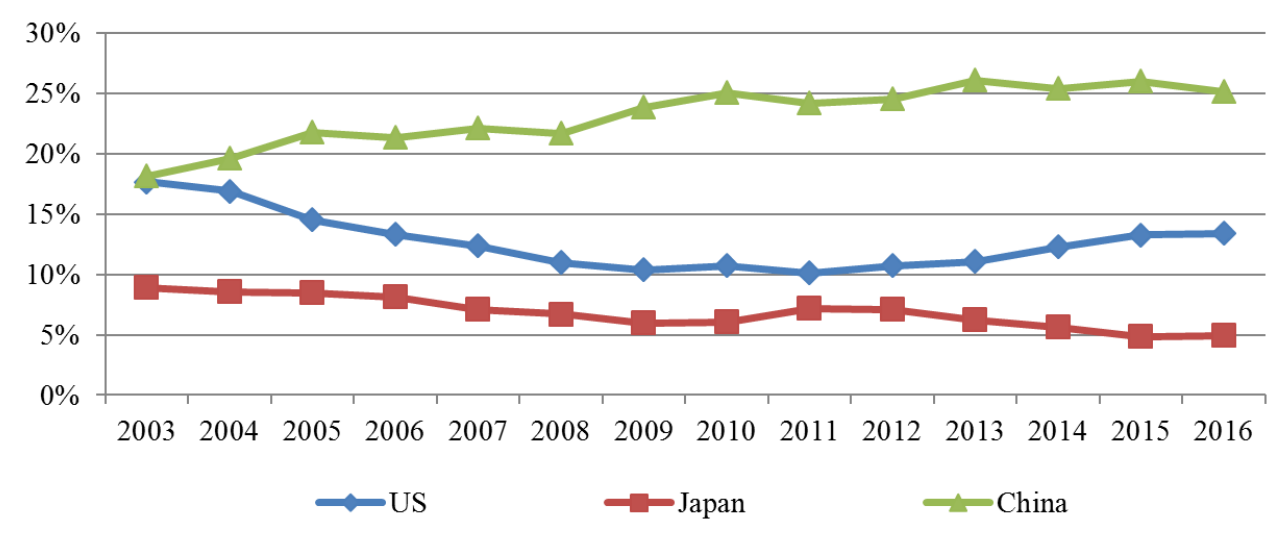

[Panel B: Imports]

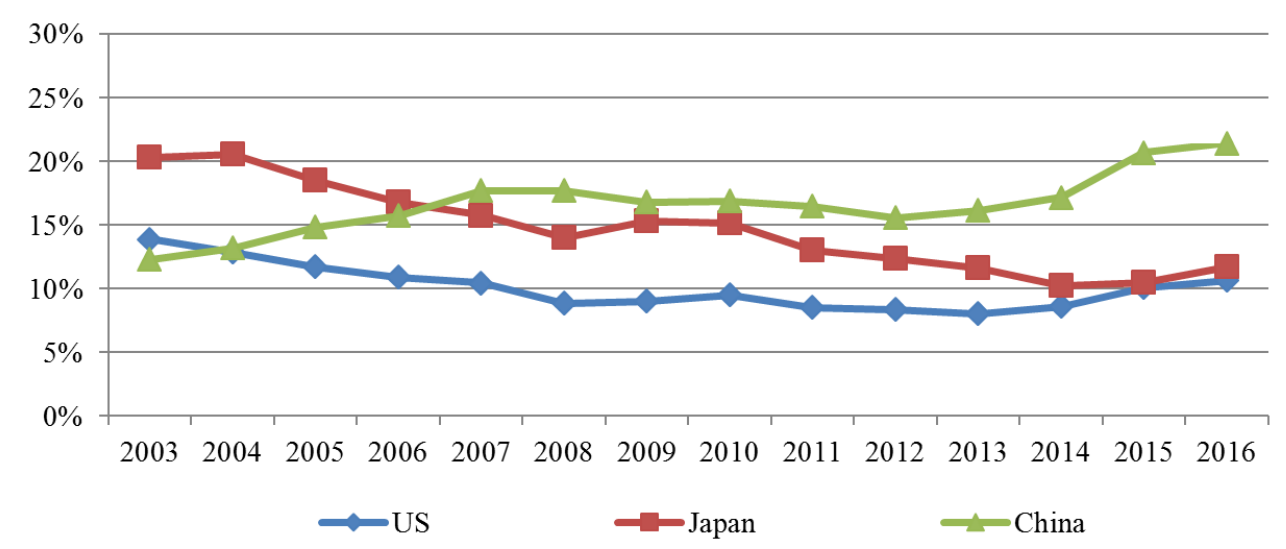


[Panel C: Trade]

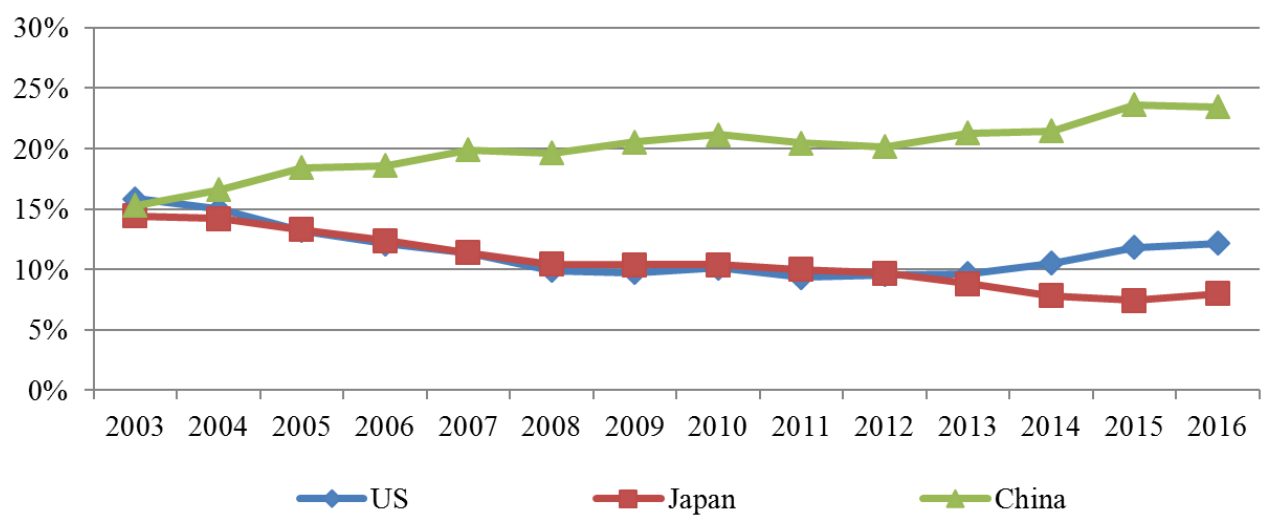

Note: Data are based on nominal amount, goods and the US dollar standards.

Sources: Bank of Korea (ECOS)

Figure 3. Market Capitalization/GDP and Foreigners' Share in Korean Stock Market

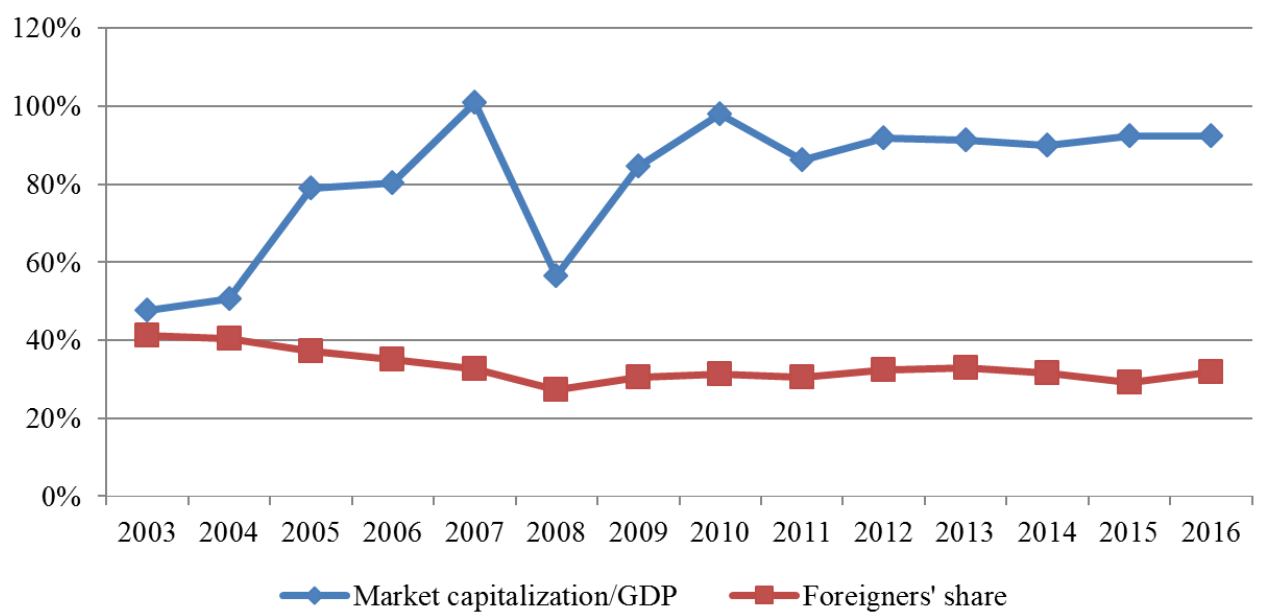

Note: Market capitalization is measured by Kospi plus Kosdak.

Sources: Bank of Korea (ECOS), Koscom and Financial Supervisory Services 
Figure 4. Shares of the US, Japan and China in Korean Stock Market

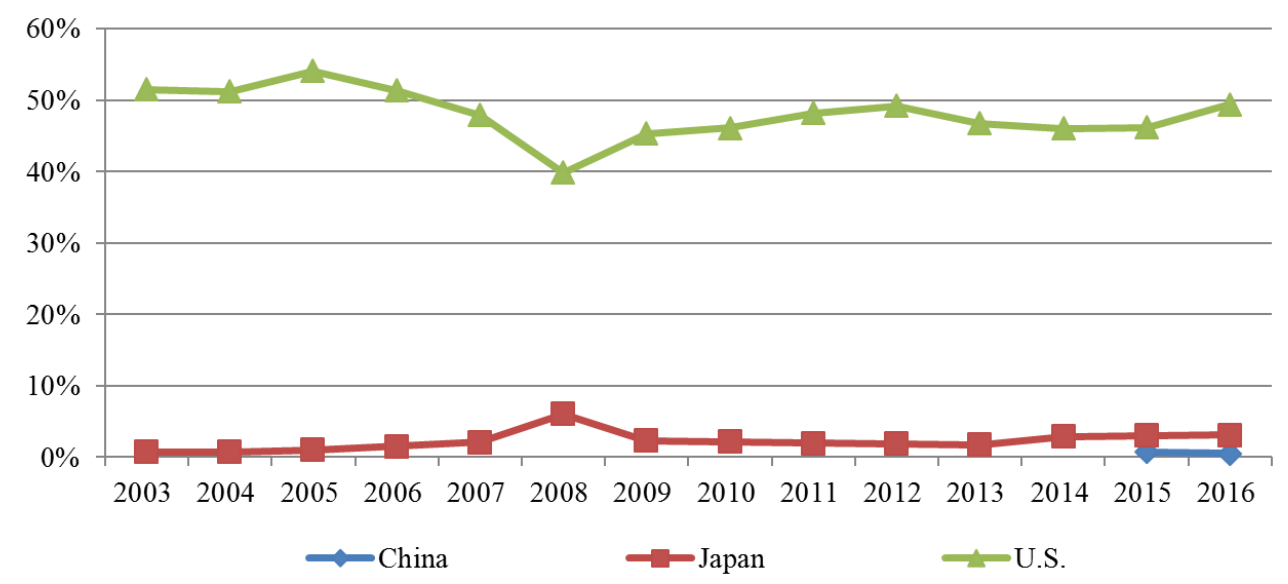

Note: The equity ratio was measured by the stock and investment fund shares.

Source: IMF (Coordinated Portfolio Investment Survey)

\section{Literature Review}

Our paper generally follows the methodology used by Forbes and Chinn (2004), Elekdag et al. (2012), and Arslanalp et al. (2016). Forbes and Chinn (2004) investigate how trade and financial linkages between five big countries (France, Germany, Japan, the UK and the US) and 38 sample countries affect comovements in stock and bond market returns from 1986 to 2000. They first estimate the impacts of bilateral, global and sectoral factors on each country's asset returns using a factor model.2) In the second stage, the bilateral factor loadings, also known as "betas," are regressed on trade-related and financial variables such as trade flows, trade competition in third markets, bank lending and foreign investment. The authors find that trade linkage variables are more significant than financial ones in explaining the factor loadings.

Elekdag et al. (2012) analyze the evolution of stock market linkages

2) The bilateral factors refer to returns for the five center countries in the asset markets; the global and sectoral factors include world market returns, global interest rates, oil prices, gold prices and commodity prices, and asset returns for 14 sectoral indexes. 
between five center countries (France, Germany, Japan, the UK and the US) and 12 Asian countries3) during the period of 1992-2011. They document that the Asian countries' financial sensitivities to the center economies increased, and both trade and financial linkages were key determinants of the sensitivities. They also argue that the Asian countries' macroeconomic policies, such as reductions in government debt and increases in foreign reserves, made limited contributions to mitigating these sensitivities.

Arslanalp et al. (2016) explore comovements in stock markets between Asian countries and four center countries (China, Japan, the euro area and the US). They build a two-stage model based on Forbes and Chinn (2004) consisting of four center economies and nine Asian countries ${ }^{4)}$ during the period of 2001-2014 (pre-crisis period: 2001-2007, crisis period: 2008-2009 and post-crisis period: 2010-2014). Their empirical results indicate that the spillover effect from China to Asian stock markets has increased since the global financial crisis, although the level of its impact is still lower than those of the US and Japan. They also report that the main driver of spillovers from the two center economies in the region (China and Japan) to other Asian stock markets is trade linkage (trade linkage for China and trade competition in third markets for Japan) rather than financial linkage.

In addition to these studies, there are other studies to examine interdependence in stock market returns between countries. Tavares (2009) examines 40 developed and emerging markets from the 1970s to 1990s and finds that bilateral trade intensity increases the correlation of stock market returns between countries, while real exchange rate volatility, asymmetry in output growth and dissimilarity in exports decrease the correlation. Eiling and Gerard (2015) find that there are significant time trends in cross-country correlations in 32 emerging markets for the period from 1991 to 2009. They argue that official market liberalization, equity

3) The 12 Asian countries include Australia, China, Hong Kong, India, Indonesia, Korea, Malaysia, New Zealand, Philippines, Singapore, Taiwan and Thailand.

4) The four center countries include China, Japan, the euro area, and the US, and the nine sample countries are Australia, India, Indonesia, Korea, Malaysia, New Zealand, Philippines, Taiwan and Thailand. 
market openness, equity market development and trade openness drive these trends. Paramati et al. $(2015$, 2016) find that trade intensity drives stock market interdependence between Australia and its trading partners.

The above-mentioned papers use aggregate and macro-level data. In contrast to these studies, our study uses industry-level data for an individual country. As there are cross-sectional variations as well as time-series variations in real and financial linkages across industries for an individual country, we can use such variations in order to examine comovements in stock returns between the individual country and foreign countries in more depth.

The literature on stock return comovements and variations across countries using industry and/or firm level data can be traced back to Roll (1992), Heston and Rouwenhorst (1994), and Griffin and Karolyi (1998).

Roll (1992) documents that industry factors such as difference or similarity of industrial composition is the main factor in explaining stock return correlations across countries. In the analysis, he uses daily stock indexes for 24 countries from April 1988 to March 1991. However, Heston and Rouwenhorst (1994) argue that variation in country stock returns is mainly due to country-specific factors rather than industry ones. Their sample includes 829 firms in 12 European countries for the period from 1978 to 1992. Griffin and Karolyi (1998) find that the industry effect is relatively larger for traded-goods industries than for nontraded-goods industries in explaining the stock return variations for 25 countries for the period from 1992 to 1995.

More recently, Brooks and Del Negro (2006) and Faias and Ferreira (2016) explore international stock market commonality using firm-level data. Brooks and Del Negro (2006) analyze the relationship between international stock market return comovement and the degree of internationalization of firms such as firm's international sales, assets and income as well as sector affiliation (traded versus non-traded). They use firm-level data composed of 1,239 firms in 20 developed and emerging countries for the period from 1985 to 2002. They find that the higher the 
degree of globalization of a firm, the higher the sensitivity of stock returns to global shocks, indicating that internationally operating firms have stronger linkages with the global stock market. Faias and Ferreira (2016) find that the stock return variation can be better explained by industry and global factors rather than country factors, using monthly stock return data from 45 countries for the period from 2001 to 2010.

There are also several studies on the stock return comovement of Korean companies using firm-level data. Park (2007) examines the impacts of analysts and foreign investors on the stock return synchronicity of Korean individual firms with the market from 2000 to 2003. The author finds that the synchronicity is greater as the number of financial analysts for a firm increases, while the impact of foreign investors measured by the equity share of foreigners in the firm is not significant. The author argues that foreign investors rely on firm-specific financial information based on the firm's intrinsic value rather than market-wide information, whereas analysts provide investors with more market-related information. Kim et al. (2015) and Cho and Mooney (2015) investigate the comovement of stock returns for firms belonging to business groups (known as chaebol) and its key determinants during the period of 1980-2009 and 2002-2011, respectively. Both papers report that companies affiliated with business groups exhibit more salient comovement in stock returns with other companies in the same business group than with companies not affiliated with the business group.

\section{Data and Methodology}

In the first stage of this paper, we measure comovements in stock returns between Korea and three countries - the US, Japan, and China - using stock returns at the industry level, and in the second stage, we examine what drives the comovements between Korea and the three countries. The three countries are chosen based on the fact that they are major trading partners of Korea. From 2003 to 2016, the Korea's average 
proportion of trade with China (20.5\%) was the highest, following by the US (11.0\%), Japan (10.0\%), Saudi Arabia (3.7\%), Hong Kong (3.2\%), and Taiwan (3.0\%).5) We choose three countries as major trading partners of Korea as each of their proportions in Korean trade was larger than $5 \%$ for the period.

In the first stage, in order to measure the comovements in stock returns between Korea and the three countries at the industry level, we use two alternative specifications, (1) and (2).

$$
\begin{aligned}
R_{i, t}= & \alpha_{i}+\beta_{u s, i} R_{u s, t}+\beta_{\text {Japan }, i} R_{\text {Japan }, t}+\beta_{\text {China }, i} R_{\text {China }, t}+\varepsilon_{i, t} \\
R_{i, t}= & \alpha_{i}+\beta_{u s, i} R_{u s, t}+\beta_{\text {Japan }, i} R_{\text {Japan }, t}+\beta_{\text {China }, i} R_{\text {China }, t}+\beta_{C R B, i} R_{C R B, t} \\
& +\beta_{U S T N, i} \Delta Y_{U S T N, t}+\beta_{V I X, i} \Delta V I X_{t}+\beta_{C D S, i} \Delta C D S_{t}+\varepsilon_{i, t}
\end{aligned}
$$

In (1), $R_{i, t}$ represents the return of industry $i$ during the week of $t$ for Korea. $R_{u s, t}, R_{\text {Japan }, t}$ and $R_{\text {China, },}$ denote the market returns during the week of $t$ for the US, Japan and China, respectively. In the first specification, we follow the spirit of the ICAPM, where the expected return of a country's stock market is influenced by global stock market returns. We use three market returns of major countries as proxies for global stock market returns. In (2), following Arslanalp et al. (2016), we add four control variables to the market returns of the US, Japan and China. The four control variables are the returns computed by $C R B$ (Commodity Research Bureau) index $\left(R_{C R B, t}\right)$, changes in the yield of US 2-year Treasury notes $\left(\triangle Y_{U S T N, t}\right)$, changes in the VIX $\left(\triangle V I X_{t}\right)$, and changes in the $C D S$ premium on Korea's 5 -year bonds from the week of $t-1$ to the week of $t$. We collect the CRB index and VIX data from Bloomberg, the yield of US 2-year Treasury notes from Federal Reserve Economic Data and the $C D S$ premium on Korea's 5 -year bonds from the Korea Center

5) We compute the proportions of trade with foreign countries for Korea using data from the Bank of Korea (ECOS). 
for International Finance. As the $C D S$ premium is regularly available from 2003, we begin our sample period from then.

In our sample, we include Korean manufacturing companies for which stocks were traded for the period from 2003 to 2016. We compute weekly stock returns (Wednesday to Wednesday) for each of the stocks using their stock prices adjusted for any distribution to stockholders such as stock splits and dividend payments. The adjusted stock prices are provided by DataGuide. We compute weekly value-weighted stock returns for each industry using all the stock returns of individual companies included in the industry. We use the market capitalization of each stock in order to compute the value-weighted stock returns for the industry. The information on the industry to which each company belongs and the market capitalization of the company are also provided by DataGuide. For the classification of industries for Korea, we use the Korean Standard Industrial Classification (KSIC, revision 9) provided by the Korea National Statistical Office.6) There are 24 divisions (industries) for manufacturing in the KSIC (revision 9). Table 1 reports the codes and names for the 24 divisions (industries). For the US, Japan and China, we compute stock market returns using the stock market return index provided by Datastream. The stock market returns are also computed weekly (Wednesday to Wednesday) for the period from 2003 to 2016. All the returns are computed in terms of local currencies.

In both (1) and (2), we run a regression for each year in our sample period and estimate the coefficients yearly in order to measure the comovements of stock returns for industry $i$ with respect to the US, Japan and China for the year.

In the second stage, in order to examine what determines the

6) The KSIC was first introduced in 1963 and is based on the UN's International Standard Industrial Classification (ISIC). There have been 10 revisions since its introduction. The $10^{\text {th }}$ revision went into effect in July 2017 . The $9^{\text {th }}$ revision, which became effective in 2008, was the latest revision in our sample period. The KSIC has a hierarchical five-digit system. The KSIC (revision 9) was divided into 21 sections, and each section is broken down into divisions (denoted by 2 digits). The divisions are further broken down into groups ( 3 digits), into classes ( 4 digits) and then into subclasses ( 5 digits). There were 76 divisions, 228 groups, 487 classes and 1,145 subclasses for the KSIC (revision 9). (source: https://unstats.un.org/unsd/cr/ctryreg) 
comovements in stock returns between Korea and the three countries at the industry level, we use three main explanatory variables: (i) the ratio of trade to sales as a proxy for trade linkage (ii) the proportion of foreign stock investment as a proxy for financial linkage and (iii) export competition in third markets. In addition, we add a dummy variable for the period of the global financial crisis (2008-2009) following Arslanalp et al. (2016) as the stock returns between Korea and the three countries may

\section{Table 1. Korean Standard Industrial Classification (revision 9) for Manufacturing}

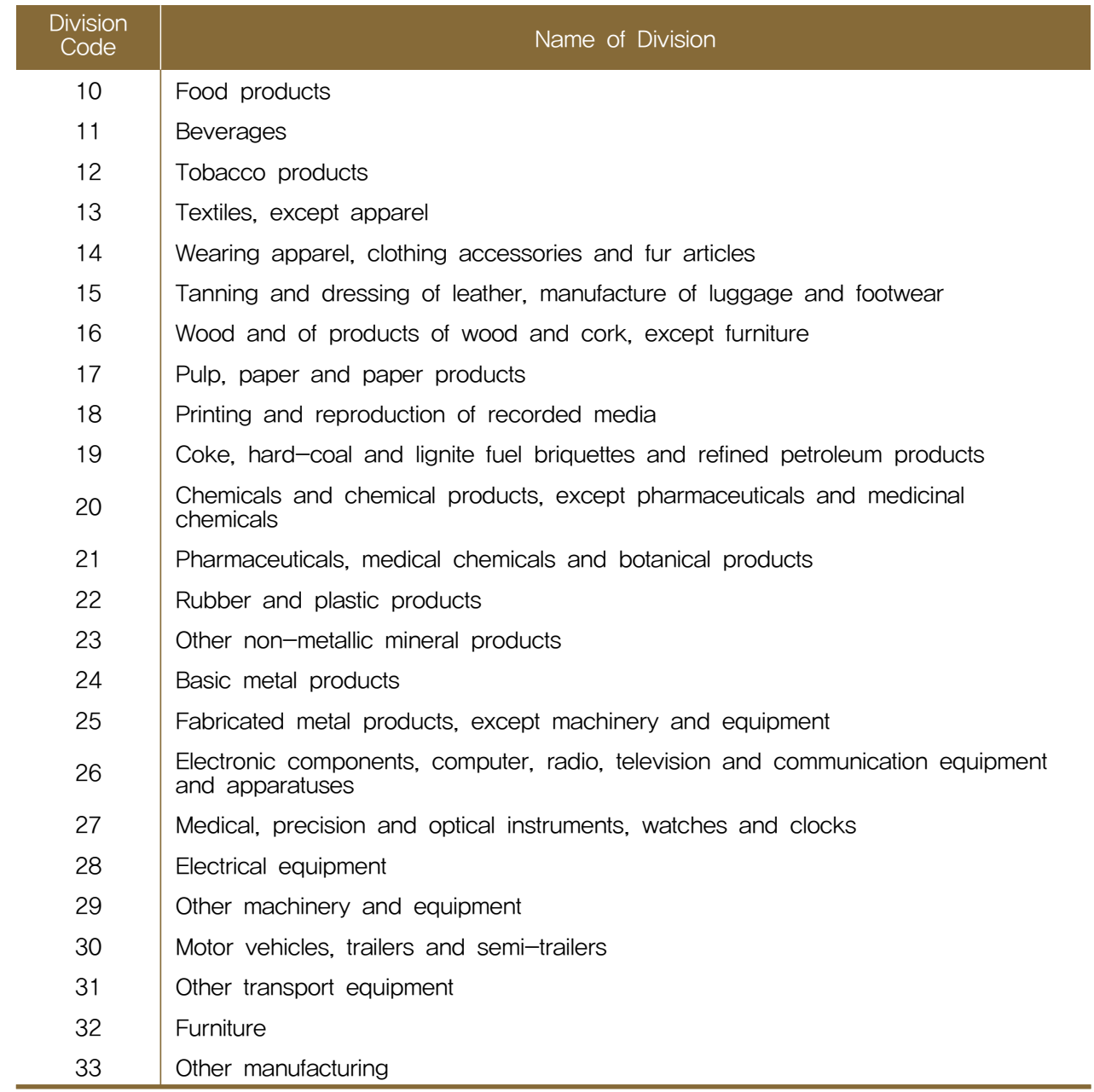

Source: Korea National Statistical Office (Korean Standard Industrial Classification, 2008) 
comove more or less during the crisis. We also consider industry effects for Korea using 23 industry dummies. The ratio of trade to sales and export competition in third markets are computed yearly for each division (industry) of Korean manufacturing for each of the three countries (the US, Japan and China). The proportion of foreign stock investment is computed for each division (industry) of Korean manufacturing for a given year. In the regression, we use the natural $\log$ of $(1+$ trade to sales ratio $\mathrm{x} 100)$ and the natural $\log$ of $(1+$ proportion of foreign stock investment $x$ 100). The specification without the dummy variables for the second stage can be shown as follows:

$$
\begin{aligned}
& \beta_{u s, i}=\delta_{u s, i}+\delta_{u s, \text { trade }} \text { Trade }_{u s, i}+\delta_{\text {us, finance }} \text { Finance }_{i} \\
& +\delta_{u s, x c} \text { Export Competition }_{u s, i}+\varepsilon_{u s, i} \\
& \beta_{\text {Japan }, i}=\delta_{\text {Japan }, i}+\delta_{\text {Japan }, \text { trade }} \text { Trade }_{\text {Japan }, i}+\delta_{\text {Japan, finance }} \text { Finance }_{i} \\
& +\delta_{\text {Japan }, x c} \text { Export Competition }{ }_{\text {Japan }, i}+\varepsilon_{\text {Japan }, i} \\
& \beta_{\text {China }, i}=\delta_{\text {China, } i}+\delta_{\text {China,trade }} \text { Trade }_{\text {China }, i}+\delta_{\text {China, finance }} \text { Finance }_{i} \\
& +\delta_{\text {China, } x c} \text { ExportCompetition } \text { China, } i+\varepsilon_{\text {China }, i}
\end{aligned}
$$

Specifically, the ratio of trade to sales for industry $i$ for a certain year for each of the three countries $\left(\right.$ Trade $_{u s, i}$, Trade Japan, $i_{\text {, and }}$ Trade $\left._{\text {China, }, i}\right)$ is computed as follows. We collect the annual exports and imports between Korea and each of the three countries in US dollars from UN Comtrade database at the level of HS 6-digit codes under HS 1996. Next, we convert HS 6-digit codes under HS 1996 to HS 6-digit codes under HS 2002 using a correspondence table provided by the UN Statistics Division.7) Then, we use two correspondence tables for 2010 Input-Output Statistics of Korea.8) The first one is a correspondence table between HS 6-digit codes 
under HS 2002 and I-O commodity codes for 2010 Input-Output Statistics of Korea. The second one is a correspondence table between I-O commodity codes and KSIC (revision 9) codes. By combining the two correspondence tables, we convert HS 6-digit codes under HS 2002 to KSIC (revision 9) codes. Next, we sum up the annual trade for all the HS 6-digit codes in each industry so that we can compute the annual trade for the industry. For the sales of each industry, we collect the annual sales in Korean won for each company within the industry from DataGuide, and compute the annual sales in Korean won for the industry by adding up the annual sales for all the companies in the industry.9) Then, we divide the annual sales for the industry in Korean won by the average exchange rate between the Korean won and US dollar for the year10) and thus compute the annual sales for the industry in US dollars. Lastly, we compute the ratio of trade to sales using the annual trade and sales in US dollars for the industry.

For the proportion of foreign stock investment each year in a Korean industry, we collect the proportion of foreign stock investment for each company in the industry at the end of each month during the sample period from DataGuide and compute the value-weighted mean of the proportions for all the companies in the industry at the end of the month. Then, we calculate the annual average of monthly proportions for the industry. Following Arslanalp et al. (2016), we compute export competition in third markets for industry $i$ each year for each of the three countries $\left(\right.$ ExportCompetition $_{u s, i}$, ExportCompetition Japan, $i$, and ExportCompetition China,$\left.i_{i}\right)$ as the minimum between the share of industry $i$ in total exports for Korea and that for each of the three countries.

Table 2 reports the averages of the trade to sales ratio, proportion of foreign stock investment and export competition for 24 Korean

\footnotetext{
8) The Bank of Korea (2014)

9) It is possible that sales data underestimate the actual amount of each industry to some degree because DataGuide does not include non-listed companies.

10) We collect the annual average exchange rate between the Korean won and US dollar from the Bank of Korea (ECOS).
} 
manufacturing divisions before the global financial crisis (2003-2007), during the global financial crisis (2008-2009), and after the global financial crisis (2010-2016). The average of the trade to sales ratio for the US decreased from $39.7 \%$ before the crisis to $26.4 \%$ after the crisis. The average of the trade to sales ratio for Japan also decreased from 45.7\% before the crisis to $27.9 \%$ after the crisis. On the other hand, the average of the trade to sales ratio for China increased from $53.4 \%$ before the crisis to $72.1 \%$ after the crisis. For the average proportion of foreign stock investment, it was $20.3 \%$ before the crisis and changed to $19.8 \%$ after the crisis. For export competition, the three countries have similar levels of competition with Korea and show little change over time.

Table 2. Trade to Sales Ratio, Proportion of Foreign Stock Investment and Export Competition for Korea (Average for 24 Manufacturing Divisions)

\begin{tabular}{|c|c|c|c|c|c|}
\hline Category & Country & $\begin{array}{c}2003-2007 \\
(A, \%)\end{array}$ & $\begin{array}{c}2008-2009 \\
(B, \%)\end{array}$ & $\begin{array}{c}2010-2016 \\
(C, \%)\end{array}$ & $(C-A, \% p)$ \\
\hline \multirow{3}{*}{$\begin{array}{l}\text { Trade } \\
\text { to Sales }\end{array}$} & US & 39.7 & 28.2 & 26.4 & -13.3 \\
\hline & Japan & 45.7 & 34.7 & 27.9 & -17.9 \\
\hline & China & 53.4 & 68.0 & 72.1 & 18.7 \\
\hline $\begin{array}{l}\text { Foreign Stock } \\
\text { Investment }\end{array}$ & All countries & 20.3 & 17.7 & 19.8 & -0.5 \\
\hline \multirow{3}{*}{ Export Competition } & US & 2.8 & 2.7 & 2.7 & -0.1 \\
\hline & Japan & 2.9 & 2.9 & 2.9 & 0.0 \\
\hline & China & 2.8 & 2.8 & 2.8 & 0.0 \\
\hline
\end{tabular}




\section{Empirical Results}

Table 3 reports the estimates of betas from specification (1), such as regression without control variables, in Section IV. Panel A of Table 3 provides the estimates of betas for 24 Korean manufacturing divisions (industries) with respect to the US and their averages for three sub-periods: before the global financial crisis (2003-2007), during the global financial crisis (2008-2009), and after the global financial crisis (2010-2016). For the US, the average betas before and after the global financial crisis are estimated to be 0.270 and 0.218 , respectively. Also, the beta after the crisis is smaller than that before the crisis for 18 out of 24 divisions. Thus, we conclude that the comovement between the Korean and US stock markets becomes smaller over time. Interestingly, the average beta during the crisis was -0.163 , and the beta was negative for 22 out of 24 divisions. This suggests that the Korean and US stock markets might have moved in opposite directions during the crisis when we control for the effects from the other two major markets, Japan and China.

Panel B of Table 3 provides the estimates of betas for 24 Korean manufacturing divisions (industries) with respect to Japan and their averages for three sub-periods. For Japan, the average betas before and after the global financial crisis are estimated to be 0.365 and 0.114 , respectively. In addition, the beta after the crisis is smaller than that before the crisis for 23 out of 24 divisions. Thus, the comovement between the Korean and Japanese stock markets also becomes smaller over time. The average beta during the crisis was 0.494, which suggests that the Korean and Japanese stock markets might have moved further in the same direction during the crisis.

Panel $\mathrm{C}$ of Table 3 provides the estimates of betas for 24 Korean manufacturing divisions (industries) with respect to China and their averages for three sub-periods. For China, the average betas before and after the global financial crisis are estimated to be 0.129 and 0.229 , respectively. Furthermore, the beta after the crisis is larger than that 
before the crisis for 20 out of 24 divisions. Thus, we conclude that the comovement between Korean and Chinese stock markets becomes larger over time. The average beta during the crisis was 0.249 . This suggests that the Korean and Chinese stock markets might have moved further in the same direction during the crisis.

Table 3. Estimates of Betas for Korean Manufacturing Industry with respect to US, Japanese and Chinese Stock Market Returns (without Control Variables)

[Panel A: US]

\begin{tabular}{|c|c|c|c|c|}
\hline Industry & $\begin{array}{c}2003-2007 \\
\text { (A) }\end{array}$ & $\begin{array}{c}2008-2009 \\
\text { (B) }\end{array}$ & $\begin{array}{c}2010-2016 \\
\text { (C) }\end{array}$ & $(C-A)$ \\
\hline 10 & 0.228 & -0.143 & 0.025 & -0.203 \\
\hline 11 & 0.192 & -0.168 & 0.100 & -0.092 \\
\hline 12 & 0.294 & -0.081 & 0.153 & -0.140 \\
\hline 13 & 0.061 & -0.151 & 0.278 & 0.217 \\
\hline 14 & 0.310 & -0.114 & 0.119 & -0.191 \\
\hline 15 & -0.006 & -0.316 & 0.543 & 0.549 \\
\hline 16 & 0.397 & -0.030 & 0.225 & -0.171 \\
\hline 17 & 0.259 & -0.233 & 0.194 & -0.065 \\
\hline 18 & 0.666 & 0.040 & 0.232 & -0.434 \\
\hline 19 & 0.273 & -0.029 & 0.257 & -0.016 \\
\hline 20 & 0.402 & -0.087 & 0.259 & -0.143 \\
\hline 21 & 0.226 & -0.220 & -0.061 & -0.288 \\
\hline 22 & 0.217 & -0.155 & 0.286 & 0.070 \\
\hline 23 & 0.213 & -0.287 & 0.214 & 0.002 \\
\hline 24 & 0.334 & 0.265 & 0.289 & -0.046 \\
\hline 25 & 0.164 & -0.440 & 0.412 & 0.248 \\
\hline 26 & 0.265 & -0.011 & 0.202 & -0.063 \\
\hline 27 & 0.462 & -0.336 & 0.230 & -0.231 \\
\hline 28 & 0.400 & -0.135 & 0.231 & -0.169 \\
\hline 29 & 0.375 & -0.350 & 0.337 & -0.038 \\
\hline 30 & 0.166 & -0.173 & 0.104 & -0.062 \\
\hline 31 & 0.147 & -0.225 & 0.381 & 0.234 \\
\hline 32 & 0.326 & -0.080 & 0.122 & -0.204 \\
\hline 33 & 0.110 & -0.446 & 0.089 & -0.021 \\
\hline Average & 0.270 & -0.163 & 0.218 & -0.052 \\
\hline
\end{tabular}


Table 3. Estimates of Betas for Korean Manufacturing Industry with respect to US, Japanese and Chinese Stock Market Returns (without Control Variables, cont'd)

[Panel B: Japan]

\begin{tabular}{|c|c|c|c|c|}
\hline Industry & $\begin{array}{c}2003-2007 \\
\text { (A) }\end{array}$ & $\begin{array}{c}2008-2009 \\
\text { (B) }\end{array}$ & $\begin{array}{c}2010-2016 \\
\text { (C) }\end{array}$ & $(C-A)$ \\
\hline 10 & 0.322 & 0.306 & 0.133 & -0.189 \\
\hline 11 & 0.329 & 0.116 & 0.116 & -0.213 \\
\hline 12 & 0.039 & 0.168 & 0.012 & -0.026 \\
\hline 13 & 0.323 & 0.403 & 0.158 & -0.165 \\
\hline 14 & 0.303 & 0.284 & 0.226 & -0.077 \\
\hline 15 & 0.278 & 0.199 & 0.059 & -0.218 \\
\hline 16 & 0.271 & 1.037 & 0.153 & -0.118 \\
\hline 17 & 0.134 & 0.483 & 0.058 & -0.075 \\
\hline 18 & 0.172 & 0.556 & 0.073 & -0.099 \\
\hline 19 & 0.170 & 0.296 & -0.080 & -0.249 \\
\hline 20 & 0.388 & 0.517 & 0.053 & -0.335 \\
\hline 21 & 0.269 & 0.440 & 0.272 & 0.003 \\
\hline 22 & 0.405 & 0.580 & 0.118 & -0.287 \\
\hline 23 & 0.426 & 0.636 & 0.115 & -0.311 \\
\hline 24 & 0.711 & 0.454 & 0.030 & -0.681 \\
\hline 25 & 0.414 & 0.744 & 0.126 & -0.288 \\
\hline 26 & 0.614 & 0.487 & 0.277 & -0.338 \\
\hline 27 & 0.391 & 0.655 & 0.104 & -0.287 \\
\hline 28 & 0.354 & 0.604 & 0.103 & -0.251 \\
\hline 29 & 0.569 & 0.788 & 0.184 & -0.385 \\
\hline 30 & 0.715 & 0.437 & -0.015 & -0.729 \\
\hline 31 & 0.545 & 0.722 & 0.195 & -0.350 \\
\hline 32 & 0.198 & 0.201 & 0.061 & -0.136 \\
\hline 33 & 0.424 & 0.754 & 0.197 & -0.227 \\
\hline Average & 0.365 & 0.494 & 0.114 & -0.251 \\
\hline
\end{tabular}


Table 3. Estimates of Betas for Korean Manufacturing Industry with respect to US, Japanese and Chinese Stock Market Returns (without Control Variables, cont'd)

[Panel C: China]

\begin{tabular}{|c|c|c|c|c|}
\hline Industry & $\begin{array}{l}2003-2007 \\
\text { (A) }\end{array}$ & $\begin{array}{l}2008-2009 \\
\text { (B) }\end{array}$ & $\begin{array}{l}2010-2016 \\
\text { (C) }\end{array}$ & $(C-A)$ \\
\hline 10 & 0.102 & 0.205 & 0.053 & -0.049 \\
\hline 11 & 0.138 & 0.207 & 0.060 & -0.078 \\
\hline 12 & -0.042 & 0.021 & -0.003 & 0.039 \\
\hline 13 & 0.162 & 0.215 & 0.130 & -0.032 \\
\hline 14 & 0.061 & 0.280 & 0.060 & -0.001 \\
\hline 15 & 0.043 & 0.512 & 0.120 & 0.077 \\
\hline 16 & 0.030 & 0.286 & 0.201 & 0.171 \\
\hline 17 & 0.038 & 0.224 & 0.179 & 0.141 \\
\hline 18 & 0.105 & -0.129 & 0.210 & 0.105 \\
\hline 19 & 0.239 & 0.251 & 0.578 & 0.339 \\
\hline 20 & 0.255 & 0.222 & 0.392 & 0.138 \\
\hline 21 & 0.113 & 0.244 & 0.117 & 0.004 \\
\hline 22 & 0.129 & 0.181 & 0.170 & 0.041 \\
\hline 23 & 0.145 & 0.312 & 0.213 & 0.069 \\
\hline 24 & 0.226 & 0.421 & 0.440 & 0.214 \\
\hline 25 & 0.130 & 0.387 & 0.240 & 0.110 \\
\hline 26 & 0.191 & 0.066 & 0.330 & 0.138 \\
\hline 27 & 0.111 & 0.363 & 0.264 & 0.154 \\
\hline 28 & 0.137 & 0.067 & 0.278 & 0.141 \\
\hline 29 & 0.166 & 0.466 & 0.304 & 0.138 \\
\hline 30 & 0.183 & 0.224 & 0.348 & 0.165 \\
\hline 31 & 0.267 & 0.556 & 0.419 & 0.152 \\
\hline 32 & 0.109 & 0.154 & 0.139 & 0.029 \\
\hline 33 & 0.062 & 0.232 & 0.247 & 0.185 \\
\hline Average & 0.129 & 0.249 & 0.229 & 0.100 \\
\hline
\end{tabular}


Table 4 reports the estimates of betas from specification (2), such as regression with control variables, in Section IV. Panel A of Table 4 provides the estimates of betas for 24 Korean manufacturing divisions (industries) with respect to the US and their averages for three sub-periods. For the US, the average betas before and after the global financial crisis are estimated to be 0.479 and 0.006 , respectively. Also, the beta after the crisis is smaller than that before the crisis for 21 out of 24 divisions. Panel B of Table 4 provides the estimates of betas for 24 Korean manufacturing divisions (industries) with respect to Japan and their averages for three sub-periods. For Japan, the average betas before and after the global financial crisis are estimated to be 0.304 and 0.124 , respectively. Moreover, the beta after the crisis is smaller than that before the crisis for 20 out of 24 divisions. Panel $\mathrm{C}$ of Table 4 provides the estimates of betas for 24 Korean manufacturing divisions (industries) with respect to China and their averages for three sub-periods. For China, the average betas before and after the global financial crisis are estimated to be 0.112 and 0.192 , respectively. In addition, the beta after the crisis is larger than that before the crisis for 19 out of 24 divisions. By industry, the increase in the value of beta was especially significant in divisions 19 (0.270), 24 (0.231) and $30(0.182)$.

When we look at the post-crisis period (2010-2016) in terms of specific Korean industries, the estimated beta with regard to China was the highest in division 19 (0.533), followed by divisions 24 (0.396), 30 (0.344), 20 (0.338), 31 (0.331) and 26 (0.320). The betas in divisions 19 (0.410), 31 (0.406), $22(0.255)$ and $30(0.254)$ were the highest with respect to the US. In the case of Japan, the betas in divisions 21 (0.327), 26 (0.255) and 31 (0.232) were the highest.

Thus, together with the results from Table 3 and Table 4 , we conclude that the comovements in stock returns between Korea and the US and between Korea and Japan become smaller over time. In contrast, the comovement in stock returns between Korea and China becomes larger over time. 
Table 4. Estimates of Betas for Korean Manufacturing Industry with respect to US, Japanese and Chinese Stock Market Returns

(with Control Variables)

[Panel A: US]

\begin{tabular}{|c|c|c|c|c|}
\hline Industry & $\begin{array}{c}2003-2007 \\
\text { (A) }\end{array}$ & $\begin{array}{l}2008-2009 \\
\text { (B) }\end{array}$ & $\begin{array}{l}2010-2016 \\
\text { (C) }\end{array}$ & $(C-A)$ \\
\hline 10 & 0.300 & -0.301 & -0.204 & -0.504 \\
\hline 11 & 0.087 & -0.401 & -0.161 & -0.248 \\
\hline 12 & 0.300 & -0.217 & 0.071 & -0.229 \\
\hline 13 & 0.378 & -0.084 & -0.144 & -0.522 \\
\hline 14 & 0.460 & 0.004 & -0.136 & -0.596 \\
\hline 15 & 0.272 & 0.177 & 0.201 & -0.071 \\
\hline 16 & 0.711 & -0.056 & -0.352 & -1.063 \\
\hline 17 & 0.429 & -0.086 & -0.044 & -0.474 \\
\hline 18 & 1.662 & 0.310 & -0.112 & -1.774 \\
\hline 19 & 0.265 & -0.141 & 0.410 & 0.145 \\
\hline 20 & 0.581 & 0.108 & 0.169 & -0.412 \\
\hline 21 & 0.389 & -0.085 & -0.249 & -0.638 \\
\hline 22 & 0.283 & 0.110 & 0.255 & -0.029 \\
\hline 23 & 0.167 & -0.274 & 0.031 & -0.136 \\
\hline 24 & 0.775 & 0.453 & -0.040 & -0.815 \\
\hline 25 & 0.466 & -0.310 & 0.030 & -0.436 \\
\hline 26 & 0.584 & 0.349 & 0.134 & -0.450 \\
\hline 27 & 1.036 & -0.104 & -0.214 & -1.250 \\
\hline 28 & 0.620 & 0.179 & 0.026 & -0.594 \\
\hline 29 & 0.743 & 0.110 & 0.179 & -0.564 \\
\hline 30 & 0.078 & 0.762 & 0.254 & 0.176 \\
\hline 31 & 0.091 & 0.260 & 0.406 & 0.315 \\
\hline 32 & 0.410 & -0.151 & -0.160 & -0.570 \\
\hline 33 & 0.407 & -0.539 & -0.197 & -0.604 \\
\hline Average & 0.479 & 0.003 & 0.006 & -0.473 \\
\hline
\end{tabular}


Table 4. Estimates of Betas for Korean Manufacturing Industry with respect to US, Japanese and Chinese Stock Market Returns (with Control Variables, cont'd)

[Panel B: Japan]

\begin{tabular}{|c|c|c|c|c|}
\hline Industry & $\begin{array}{c}2003-2007 \\
\text { (A) }\end{array}$ & $\begin{array}{l}2008-2009 \\
\text { (B) }\end{array}$ & $\begin{array}{c}2010-2016 \\
\text { (C) }\end{array}$ & $(C-A)$ \\
\hline 10 & 0.265 & 0.169 & 0.140 & -0.125 \\
\hline 11 & 0.247 & 0.051 & 0.171 & -0.076 \\
\hline 12 & 0.057 & 0.184 & 0.060 & 0.003 \\
\hline 13 & 0.295 & 0.227 & 0.150 & -0.145 \\
\hline 14 & 0.163 & 0.088 & 0.192 & 0.029 \\
\hline 15 & 0.299 & -0.087 & 0.036 & -0.263 \\
\hline 16 & 0.223 & 0.689 & 0.198 & -0.025 \\
\hline 17 & 0.059 & 0.361 & 0.082 & 0.023 \\
\hline 18 & 0.130 & 0.519 & 0.060 & -0.070 \\
\hline 19 & 0.116 & 0.134 & -0.051 & -0.167 \\
\hline 20 & 0.276 & 0.313 & 0.081 & -0.195 \\
\hline 21 & 0.202 & 0.457 & 0.327 & 0.125 \\
\hline 22 & 0.367 & 0.312 & 0.121 & -0.246 \\
\hline 23 & 0.379 & 0.476 & 0.123 & -0.256 \\
\hline 24 & 0.578 & 0.149 & 0.080 & -0.499 \\
\hline 25 & 0.321 & 0.398 & 0.145 & -0.176 \\
\hline 26 & 0.587 & 0.317 & 0.255 & -0.332 \\
\hline 27 & 0.362 & 0.491 & 0.070 & -0.291 \\
\hline 28 & 0.282 & 0.434 & 0.100 & -0.183 \\
\hline 29 & 0.500 & 0.512 & 0.183 & -0.317 \\
\hline 30 & 0.656 & 0.040 & -0.028 & -0.684 \\
\hline 31 & 0.420 & 0.309 & 0.232 & -0.188 \\
\hline 32 & 0.182 & 0.185 & 0.058 & -0.124 \\
\hline 33 & 0.336 & 0.545 & 0.189 & -0.148 \\
\hline Average & 0.304 & 0.303 & 0.124 & -0.180 \\
\hline
\end{tabular}


Table 4. Estimates of Betas for Korean Manufacturing Industry with respect to US, Japanese and Chinese Stock Market Returns (with Control Variables, cont'd)

[Panel C: China]

\begin{tabular}{|c|c|c|c|c|}
\hline Industry & $\begin{array}{l}2003-2007 \\
\text { (A) }\end{array}$ & $\begin{array}{l}2008-2009 \\
\text { (B) }\end{array}$ & $\begin{array}{l}2010-2016 \\
\text { (C) }\end{array}$ & $(C-A)$ \\
\hline 10 & 0.083 & 0.096 & 0.041 & -0.043 \\
\hline 11 & 0.130 & 0.163 & 0.016 & -0.114 \\
\hline 12 & -0.033 & -0.032 & -0.001 & 0.032 \\
\hline 13 & 0.169 & 0.065 & 0.107 & -0.061 \\
\hline 14 & 0.033 & 0.125 & -0.023 & -0.055 \\
\hline 15 & 0.042 & 0.396 & 0.058 & 0.016 \\
\hline 16 & -0.017 & 0.101 & 0.147 & 0.164 \\
\hline 17 & 0.008 & 0.150 & 0.141 & 0.133 \\
\hline 18 & 0.097 & -0.155 & 0.140 & 0.043 \\
\hline 19 & 0.263 & 0.149 & 0.533 & 0.270 \\
\hline 20 & 0.209 & 0.142 & 0.338 & 0.129 \\
\hline 21 & 0.126 & 0.174 & 0.110 & -0.016 \\
\hline 22 & 0.112 & 0.035 & 0.157 & 0.045 \\
\hline 23 & 0.106 & 0.191 & 0.166 & 0.060 \\
\hline 24 & 0.165 & 0.348 & 0.396 & 0.231 \\
\hline 25 & 0.112 & 0.235 & 0.188 & 0.076 \\
\hline 26 & 0.186 & -0.007 & 0.320 & 0.135 \\
\hline 27 & 0.081 & 0.228 & 0.231 & 0.150 \\
\hline 28 & 0.107 & 0.000 & 0.278 & 0.171 \\
\hline 29 & 0.131 & 0.380 & 0.270 & 0.139 \\
\hline 30 & 0.162 & 0.173 & 0.344 & 0.182 \\
\hline 31 & 0.272 & 0.411 & 0.331 & 0.059 \\
\hline 32 & 0.086 & 0.142 & 0.114 & 0.029 \\
\hline 33 & 0.048 & 0.055 & 0.212 & 0.163 \\
\hline Average & 0.112 & 0.149 & 0.192 & 0.081 \\
\hline
\end{tabular}


Table 5 reports the results of a regression analysis where we examine the drivers of comovements in stock returns between Korea and the three countries. In Panel A of Table 5, we use the betas for 24 Korean manufacturing divisions (industries) with respect to the US from specifications (1) and (2) in Section IV, such as regression without and with control variables, as dependent variables. When we use the beta from specification (1), i.e. without control variables, as a dependent variable, and variables on trade flows, foreign stock investment and export competition in third markets as independent variables, the variable of trade is positive and significant at the 5\% level, but the variables of foreign stock investment and export competition are not significant at any conventional level. When we add a dummy variable for the global financial crisis, none of the three variables is significant. When we use the beta from specification (2), i.e. with control variables, as a dependent variable, the variable of trade is positive and significant at the 5\% level, but the variables of foreign stock investment and export competition are not statistically significant. When we add a dummy variable for the global financial crisis, the variable of trade is still positive and significant at the $5 \%$ level. However, the variables of foreign stock investment and export competition are not significant. Thus, in the case of the US, we conclude that the variable of trade has a positive relationship with beta, but the variables of foreign stock investment and export competition have no relationship with beta.

In Panel B of Table 5, we use the betas for 24 Korean manufacturing divisions (industries) with respect to Japan from specifications (1) and (2) as dependent variables. When we use the beta from specification (1) as a dependent variable, the variable of trade is positive and significant at the $1 \%$ level, but the variables of foreign stock investment and export competition are not significant. When we add a dummy variable for the global financial crisis, the variable of trade is still positive and significant at the $1 \%$ level, but the variables of foreign stock investment and export competition are not significant. When we use the beta from specification 
(2) as a dependent variable and variables on trade and foreign stock investment as independent variables, the variable of trade is still positive and significant at the $5 \%$ level, but the variables of foreign stock investment and export competition are not significant. When we add a dummy variable for the global financial crisis, the variable of trade is still positive and significant at the $5 \%$ level. However, the variable of foreign stock investment and export competition are not significant. Thus, in the case of Japan, we conclude that the variable of trade has a positive relationship with beta, but the variables of foreign stock investment and export competition have no relationship with beta.

In Panel $\mathrm{C}$ of Table 5, we use the betas for 24 Korean manufacturing divisions (industries) with respect to China from specifications (1) and (2) as dependent variables. When we use the beta from specification (1) as a dependent variable, the variable of trade is positive and significant at the $1 \%$ level, but the variables of foreign stock investment and export competition are not statistically significant. When we add a dummy variable for the global financial crisis, the variable of trade is still positive and significant at the $1 \%$ level, but the variables of foreign stock investment and export competition are not significant. When we use the beta from specification (2) as a dependent variable, the variable of trade is still positive and significant at the $10 \%$ level, but the variables of foreign stock investment and export competition are not significant. When we add a dummy variable for the global financial crisis, the variable of trade is still positive and significant at the $10 \%$ level. However, the variables of foreign stock investment and export competition are not significant. Therefore, in the case of China, we conclude that the variable of trade has a positive relationship with beta, but the variables of foreign stock investment and export competition have no relationship with beta.

Together with the results for the US, Japan and China, we conclude that trade linkage is the main driver of comovements in stock returns between Korea and the three major countries. We find no evidence that either financial linkage proxied by foreign stock investment or export 
competition is related to comovements in stock returns between Korea and the three countries. We also admit that the proxy used for measuring bilateral financial linkage between Korea and the three countries in our paper has some limitations to explain the interconnection.

\section{Table 5. Regression of Beta on Trade, Foreign Stock Investment and Export Competition for Korean Manufacturing Industry}

[Panel A: US]

\begin{tabular}{|c|c|c|c|c|}
\hline \multirow{3}{*}{ Independent Variables } & \multicolumn{4}{|c|}{ Dependent Variable } \\
\hline & \multicolumn{4}{|c|}{ Beta of Korean Manufacturing Industry } \\
\hline & \multicolumn{2}{|c|}{ Without Control Variables } & \multicolumn{2}{|c|}{ With Control Variables } \\
\hline Trade & $\begin{array}{l}0.161^{* *} \\
(2.11)\end{array}$ & $\begin{array}{l}0.082 \\
(1.12)\end{array}$ & $\begin{array}{l}0.335^{* *} \\
(2.44)\end{array}$ & $\begin{array}{l}0.301^{* *} \\
(2.20)\end{array}$ \\
\hline Finance & $\begin{array}{l}0.007 \\
(0.09)\end{array}$ & $\begin{array}{l}-0.031 \\
(-0.45)\end{array}$ & $\begin{array}{l}-0.068 \\
(-0.63)\end{array}$ & $\begin{array}{l}-0.084 \\
(-0.78)\end{array}$ \\
\hline ExportCompetition & $\begin{array}{l}-0.009 \\
(-0.34)\end{array}$ & $\begin{array}{l}-0.006 \\
(-0.24)\end{array}$ & $\begin{array}{l}-0.008 \\
(-0.18)\end{array}$ & $\begin{array}{l}-0.006 \\
(-0.15)\end{array}$ \\
\hline Crisis Dummy & & $\begin{array}{c}-0.395^{* * *} \\
(-7.55)\end{array}$ & & $\begin{array}{c}-0.169^{* *} \\
(-2.17)\end{array}$ \\
\hline Industry Effect & Yes & Yes & Yes & Yes \\
\hline N & 336 & 336 & 336 & 336 \\
\hline $\mathrm{R}^{2}$ & 0.054 & 0.166 & 0.079 & 0.087 \\
\hline
\end{tabular}

Notes: 1) Numbers in parentheses are heteroscedasticity-robust t-statistics.

2) ${ }^{* * *},{ }^{* *}$, and ${ }^{*}$ denote statistical significance at the level of $1 \%, 5 \%$ and $10 \%$, respectively. 
Table 5. Regression of Beta on Trade, Foreign Stock Investment and Export Competition for Korean Manufacturing Industry (cont'd)

[Panel B: Japan]

\begin{tabular}{|c|c|c|c|c|}
\hline \multirow{3}{*}{ Independent Variables } & \multicolumn{4}{|c|}{ Dependent Variable } \\
\hline & \multicolumn{4}{|c|}{ Beta of Korean Manufacturing Industry } \\
\hline & Without & Variables & With $\mathrm{Cc}$ & ariables \\
\hline Trade & $\begin{array}{c}0.225^{* * *} \\
(3.70)\end{array}$ & $\begin{array}{c}0.230^{* * *} \\
(4.02)\end{array}$ & $\begin{array}{c}0.123^{* *} \\
(2.10)\end{array}$ & $\begin{array}{c}0.128^{* *} \\
(2.17)\end{array}$ \\
\hline Finance & $\begin{array}{l}0.057 \\
(0.95)\end{array}$ & $\begin{array}{l}0.074 \\
(1.35)\end{array}$ & $\begin{array}{l}0.022 \\
(0.41)\end{array}$ & $\begin{array}{l}0.029 \\
(0.55)\end{array}$ \\
\hline ExportCompetition & $\begin{array}{l}-0.012 \\
(-0.72)\end{array}$ & $\begin{array}{l}-0.010 \\
(-0.63)\end{array}$ & $\begin{array}{l}0.005 \\
(0.28)\end{array}$ & $\begin{array}{l}0.006 \\
(0.33)\end{array}$ \\
\hline Crisis Dummy & & $\begin{array}{c}0.279^{* * *} \\
(7.10)\end{array}$ & & $\begin{array}{c}0.105^{* * *} \\
(2.73)\end{array}$ \\
\hline Industry Effect & Yes & Yes & Yes & Yes \\
\hline N & 336 & 336 & 336 & 336 \\
\hline$R^{2}$ & 0.143 & 0.240 & 0.102 & 0.118 \\
\hline
\end{tabular}

Notes: 1) Numbers in parentheses are heteroscedasticity-robust t-statistics.

2) ${ }^{* * *},{ }^{* *}$, and ${ }^{*}$ denote statistical significance at the level of $1 \%, 5 \%$ and $10 \%$, respectively. 


\section{Table 5. Regression of Beta on Trade, Foreign Stock Investment and Export Competition for Korean Manufacturing Industry (cont'd)}

[Panel C: China]

\begin{tabular}{|c|c|c|c|c|}
\hline \multirow{3}{*}{ Independent Variables } & \multicolumn{4}{|c|}{ Dependent Variable } \\
\hline & \multicolumn{4}{|c|}{ Beta of Korean Manufacturing Industry } \\
\hline & \multicolumn{2}{|c|}{ Without Control Variables } & \multicolumn{2}{|c|}{ With Control Variables } \\
\hline Trade & $\begin{array}{c}0.134^{* * *} \\
(3.11)\end{array}$ & $\begin{array}{c}0.132^{* * *} \\
(2.98)\end{array}$ & $\begin{array}{l}0.087^{*} \\
(1.95)\end{array}$ & $\begin{array}{l}0.087^{*} \\
(1.96)\end{array}$ \\
\hline Finance & $\begin{array}{l}0.019 \\
(0.70)\end{array}$ & $\begin{array}{l}0.022 \\
(0.83)\end{array}$ & $\begin{array}{l}0.023 \\
(0.77)\end{array}$ & $\begin{array}{l}0.022 \\
(0.75)\end{array}$ \\
\hline ExportCompetition & $\begin{array}{l}-0.014 \\
(-1.06)\end{array}$ & $\begin{array}{l}-0.013 \\
(-1.03)\end{array}$ & $\begin{array}{l}-0.004 \\
(-0.32)\end{array}$ & $\begin{array}{l}-0.005 \\
(-0.33)\end{array}$ \\
\hline Crisis Dummy & & $\begin{array}{l}0.060 \\
(1.69)\end{array}$ & & $\begin{array}{l}-0.011 \\
(-0.33)\end{array}$ \\
\hline Industry Effect & Yes & Yes & Yes & Yes \\
\hline N & 336 & 336 & 336 & 336 \\
\hline$R^{2}$ & 0.239 & 0.248 & 0.212 & 0.212 \\
\hline
\end{tabular}

Notes: 1) Numbers in parentheses are heteroscedasticity-robust t-statistics.

$2{ }^{* * *},{ }^{* *}$, and ${ }^{*}$ denote statistical significance at the level of $1 \%, 5 \%$ and $10 \%$, respectively.

\section{Conclusion}

This paper measures the extent of comovements in stock returns between Korea and three major countries (China, Japan and the US) using the industry-level data for Korea from 2003 to 2016, in the spirit of the ICAPM. It also examines what drives the comovements between Korea and the three countries.

From our analysis, we find that the comovements of the Korean stock market with those of the US and Japan became smaller after the global financial crisis. In contrast, the post-crisis comovement in stock returns 
between Korea and China is larger than that of the pre-crisis period.

Next, we examine the drivers of comovements in stock returns between Korea and the three countries. Specifically, we use betas for 24 Korean manufacturing divisions (industries) with respect to the US, Japan and China as dependent variables, and variables on trade and foreign stock investment as independent variables, so that we can examine whether either trade or financial linkage between Korea and the three countries may explain the degrees of comovements in stock returns between Korea and the three countries. From our analysis, we find that trade linkage is the main driver of comovements in stock returns between Korea and the three countries. On the other hand, we find no evidence that financial linkage proxied by foreign stock investment is related to comovements in stock returns between Korea and the three countries.

Our finding that trade linkage with foreign countries has an effect on the domestic financial market suggests that the concentration of trade with some trading partners may become a destabilizing factor in the domestic financial market, if there is a negative shock in trade with those partners. Thus, it is important for Korea to diversify trade with foreign countries to keep its financial market more stable. In this regard, it will be also useful to further study the effects of trade diversification on the real economy and financial markets. 


\section{References}

Arslanalp, S., W. Liao, S. Piao and D. Seneviratne (2016), "China's Growing Influence on Asian Financial Markets," IMF Working Paper, WP/16/173.

Brooks, R. and M. Del Negro (2006), "Firm-Level Evidence on International Stock Market Comovement," Review of Finance, Vol. 10, pp. 69-98.

Cho, C. and T. Mooney (2015), "Stock Return Comovement and Korean Business Groups," Review of Development Finance, Vol. 5, pp. 71-81.

Didier T., I. Love and M. Peria (2012), "What Explains Comovement in Stock Market Returns during the 2007-2008 Crisis?" International Journal of Finance and Economics, Vol. 17, pp. 182-202.

Eiling, E. and B. Gerard (2015), "Emerging Equity Market Comovements: Trends and Macroeconomic Fundamentals," Review of Finance, Vol. 19, pp. 1543-1585.

Elekdag, S., P. Rungcharoenkitkul and Y. Wu (2012), "The Evolution of Asian Financial Linkages: Key Determinants and the Role of Policy," IMF Working Paper, WP/12/262.

Faias, J. and M. Ferreira (2016), "Does Institutional Ownership Matter for International Stock Return Comovement?” ECGI Working Paper No. 465.

Forbes, K. and M. Chinn (2016), "A Decomposition of Global Linkages in financial Markets over Time," Review of Economics and Statistics, Vol. 86(3), pp. 705-722.

Griffin, J. and A. Karolyi (1998), "Another Look at the Role of Industrial Structure of Markets for International Strategies," Journal of Financial Economics, Vol. 50, pp. 351-373.

Heston, S. and K. Rouwenhorst (1994), "Does Industrial Structure Explain the Benefits of International Diversification?" Journal of Financial Economics, Vol. 36, pp. 3-27.

Kim, M., W. Kim and D. Lee (2015), "Stock Return Commonality within Business Groups: Fundamentals or Sentiment?" Pacific-Basin Finance Journal, Vol. 35, pp. 198-224. 
Paramati, S., R. Gupta and E. Roca (2015), "Stock Market Interdependence between Australia and Its Trading Partners: Does Trade Intensity Matter?" Applied Economics, Vol. 47(49), pp. 5303-5319.

Paramati, S., R. Gupta and E. Roca (2016), "Economic Integration and Stock Market Dynamic Linkages: Evidence in the Context of Australia and Asia," Applied Economics, Vol. 48(44), pp. 4210-4226.

Park, K. (2007), "Stock Price Synchronicity and Analyst \& Foreign Investor Activity," Korean Journal of Business Administration, Vol. 20(6), pp. 2753-2775.

Roll, R. (1992), "Industrial Structure and the Comparative Behavior of International Stock Market Indices," Journal of Finance, Vol. 47(1), pp. $3-41$.

Tavares, J. (2009), "Economic Integration and the Comovement of Stock Returns," Economics Letters, Vol. 103, pp. 65-67. 


\section{$<$ Abstract in Korean $>$}

\section{한국과 중국, 일본, 미국 간 주식시장 동조성 결정요인은 무엇인가?}

\section{이진수*, 유복근**}

본 고는 국제자본자산가격 모형(ICAPM: International Capital Asset Pricing Model)에 기반을 두고 2003-2016년 중 한국의 산업 데이타를 이용 하여 한국과 중국, 일본, 미국 간 주식시장 동조성의 정도를 측정한 후 이를 결정하는 주요한 요인이 무엇인지 분석하였다.

실증분석 결과, 한국-미국과 한국-일본의 경우 글로벌 금융위기 이후 주 식수익률의 동조성이 작아졌으나 한국-중국은 오히려 커진 것으로 나타났다. 또한 무역연계성이 한국과 이들 3 개국과의 동조성을 결정하는 주요인이었다.

이러한 결과는 일부 국가와의 무역집중은 이들 국가와의 무역에서 발생 하는 부정적인 충격이 국내 금융시장의 불안정 요인으로 작용할 수 있음을 시사한다. 이러한 점에 비추어 볼 때, 우리나라의 금융시장을 안정적으로 유 지하기 위해서는 외국과의 무역다변화 필요성도 제기된다.

핵심 주제어: 주식시장 동조성, 무역연계성, 금융연계성

JEL Classification: F15, F21, G15

\footnotetext{
* KDI 국제정책대학원 교수 (전화: 044-550-1060, E-mail: jlee@kdischool.ac.kr)

** 한국은행 경제연구원 미시제도연구실 연구위원 (전화: 02-759-5461, E-mail: bokyu@bok.or.kr)
}

본 연구내용은 집필자의 개인의견이며 한국은행의 공식견해와는 무관합니다. 따라서 본 논문의 내용을 보도하거나 인용할 경우에는 집필자 명을 반드시 명시하여 주시기 바랍니다. 


\section{$\mathrm{BOK}$ 경제연구 발간목록}

한국은행 경제연구원에서는 Working Paper인 『BOK 경제연구』를 수시로 발간하고 있습니다. ${ }^{『} \mathrm{BOK}$ 경제연구』는 주요 경제 현상 및 정책 효과에 대한 직관적 설명 뿐 아니라 깊이 있는 이론 또는 실증 분석을 제공함으로써 엄밀한 논증에 초점을 두는 학술논문 형태의 연구이며 한국은행 직원 및 한국은행 연구용역사업의 연구 결과물이 수록되고 있습니다.

『BOK 경제연구』는 한국은행 경제연구원 홈페이지(http://imer.bok.or.kr)에서 다운로드하여 보실 수 있습니다.

\section{제2014-1 Network Indicators for Monitoring} Intraday Liquidity in BOK-Wire+

2 중소기업에 대한 신용정책 효과

3 경제충격 효과의 산업간 공행성 분석

4 서비스업 발전을 통한 내외수 균형성장: 기대효과 및 리스크

5 Cross-country-heterogeneous and Time-varying Effects of Unconventional Monetary Policies in AEs on Portfolio Inflows to EMEs

6 인터넷뱅킹, 결제성예금 및 은행 수익성과의 관계 분석

7 Dissecting Foreign Bank Lending Behavior During the 2008-2009 Crisis

8 The Impact of Foreign Banks on Monetary Policy Transmission during the Global Financial Crisis of 2008-2009: Evidence from Korea

9 Welfare Cost of Business Cycles in Economies with Individual Consumption Risk

10 Investor Trading Behavior Around the Time of Geopolitical Risk Events: Evidence from South Korea

11 Imported-Inputs Channel of Exchange Rate Pass-Through: Evidence from Korean Firm-Level Pricing Survey
Seungjin Baek •

Kimmo Soram ki • Jaeho Yoon

정호성·임호성

황선웅 - 민성환 ·

신동현·김기호

김승원 · 황광명

Kyoungsoo Yoon •

Christophe Hurlin

이동규·전봉걸

Moon Jung Choi •

Eva Gutierrez •

Maria Soledad Martinez Peria

Bang Nam Jeon •

Hosung Lim $\cdot$ Ji Wu

Martin Ellison •

Thomas J. Sargent

Young Han Kim •

Hosung Jung

Jae Bin Ahn •

Chang-Gui Park 


\begin{tabular}{|c|c|c|}
\hline 제2014-12 & 비대칭 금리기간구조에 대한 실증분석 & 김기호 \\
\hline 13 & $\begin{array}{l}\text { The Effects of Globalization } \\
\text { on Macroeconomic Dynamics } \\
\text { in a Trade-Dependent Economy: } \\
\text { the Case of Korea }\end{array}$ & Fabio Milani · Sung Ho Park \\
\hline 14 & $\begin{array}{l}\text { 국제 포트폴리오투자 행태 분석: 채권-주식 } \\
\text { 투자자금간 상호관계를 중심으로 }\end{array}$ & 이주용·김근영 \\
\hline 15 & $\begin{array}{l}\text { 북한 경제의 추격 성장 가능성과 } \\
\text { 정책 선택 시나리오 }\end{array}$ & 이근 · 최지영 \\
\hline 16 & $\begin{array}{l}\text { Mapping Korea's International Linkages } \\
\text { using Generalised Connectedness Measures }\end{array}$ & Hail Park $\cdot$ Yongcheol Shin \\
\hline 17 & $\begin{array}{l}\text { 국제자본이동 하에서 환율신축성과 } \\
\text { 경상수지 조정: 국가패널 분석 }\end{array}$ & 김근영 \\
\hline 18 & $\begin{array}{l}\text { 외국인 투자자가 외환시장과 주식시장 간 } \\
\text { 유동성 동행화에 미치는 영향 }\end{array}$ & 김준한 $\cdot$ 이지은 \\
\hline 19 & $\begin{array}{l}\text { Forecasting the Term Structure } \\
\text { of Government Bond Yields } \\
\text { Using Credit Spreads and Structural Breaks }\end{array}$ & $\begin{array}{l}\text { Azamat Abdymomunov } \\
\text { Kyu Ho Kang } \\
\text { Ki Jeong Kim }\end{array}$ \\
\hline 20 & $\begin{array}{l}\text { Impact of Demographic Change } \\
\text { upon the Sustainability of Fiscal Policy }\end{array}$ & $\begin{array}{l}\text { Younggak Kim· } \\
\text { Myoung Chul Kim } \\
\text { Seongyong Im }\end{array}$ \\
\hline 21 & $\begin{array}{l}\text { The Impact of Population Aging } \\
\text { on the Countercyclical Fiscal Stance in Korea, } \\
\text { with a Focus on the Automatic Stabilizer }\end{array}$ & $\begin{array}{l}\text { Tae-Jeong Kim } \cdot \\
\text { Mihye Lee } \cdot \text { Robert Dekle }\end{array}$ \\
\hline 22 & $\begin{array}{l}\text { 미 연준과 유럽중앙은행의 비전통적 통화정책 } \\
\text { 수행원칙에 관한 고찰 }\end{array}$ & 김병기· 김진일 \\
\hline 23 & $\begin{array}{l}\text { 우리나라 일반인의 인플레이션 기대 형성 } \\
\text { 행태 분석 }\end{array}$ & 이한규·최진호 \\
\hline
\end{tabular}


제2014-24 Nonlinearity in Nexus between

Working Hours and Productivity

25 Strategies for Reforming Korea's Labor Market to Foster Growth

26 글로벌 금융위기 이후 성장잠재력 확충: 2014 한국은행 국제컨퍼런스 결과보고서

27 인구구조 변화가 경제성장률에 미치는 영향: 자본이동의 역할에 대한 논의를 중심으로

28 Safe Assets

29 확장된 실업지표를 이용한 우리나라 노동시장에서의 이력현상 분석

Entropy of Global Financial Linkages

31 International Currencies Past, Present and Future: Two Views from Economic History

32 금융체제 이행 및 통합 사례:

남북한 금융통합에 대한 시사점

Measuring Price-Level Uncertainty and Instability in the U.S., 1850-2012

고용보호제도가 노동시장 이원화

및 노동생산성에 미치는 영향

35 해외충격시 외화예금의 역할 : 주요 신흥국 신용스프레드에 미치는 영향을 중심으로 Emerging Market Economies, and Their Policy Responses
Dongyeol Lee •

Hyunjoon Lim

Mai Dao · Davide Furceri ·

Jisoo Hwang .

Meeyeon Kim •

Tae-Jeong Kim

한국은행 경제연구원

손종칠

Robert J. Barro

김현학 · 황광명

Daeyup Lee

Barry Eichengreen

김병연

Timothy Cogley •

Thomas J. Sargent

김승원

정호성 - 우준명

김인수 · 이명수

황광명 · 김경민 ·

노충식·김미진

Woon Gyu Choi •

Taesu Kang •

Geun-Young Kim •

Byongju Lee 
제2015-1 글로벌 금융위기 이후 주요국

통화정책 운영체계의 변화

2 미국 장기시장금리 변동이 우리나라 금리기간구조에 미치는 영향 분석 및 정책적 시사점

3 직간접 무역연계성을 통한 해외충격의 우리나라 수출입 파급효과 분석

4 통화정책 효과의 지역적 차이

5 수입중간재의 비용효과를 고려한 환율변동과 수출가격 간의 관계

6 중앙은행의 정책금리 발표가 주식시장 유동성에 미치는 영향

7 은행 건전성지표의 변동요인과 거시건전성 규제의 영향

8 Price Discovery and Foreign Participation in The Republic of Korea's Government Bond Futures and Cash Markets

9 규제가 노동생산성에 미치는 영향:

한국의 산업패널 자료를 이용한 실증분석

10 인구 고령화와 정년연장 연구

(세대 간 중첩모형(OLG)을 이용한 정량 분석)

11 예측조합 및 밀도함수에 의한 소비자물가 상승률 전망

12 인플레이션 동학과 통화정책

13 Failure Risk and the Cross-Section of Hedge Fund Returns

14 Global Liquidity and Commodity Prices

15 Foreign Ownership, Legal System and Stock Market Liquidity
김병기·김인수

강규호·오형석

최문정·김근영

김기호

김경민

이지은

강종구

Jaehun Choi - Hosung Lim •

Rogelio Jr. Mercado •

Cyn-Young Park

이동렬· 최종일·이종한

홍재화 - 강태수

김현학

우준명

Jung-Min Kim

Hyunju Kang •

Bok-Keun $\mathrm{Yu}$.

Jongmin $\mathrm{Yu}$

Jieun Lee $\cdot$ Kee H. Chung 
제2015-16 바젤피 은행 경기대응완충자본 규제의 기준지표에 대한 연구

17 우리나라 대출 수요와 공급의 변동요인 분석

18 북한 인구구조의 변화 추이와 시사점

19 Entry of Non-financial Firms and Competition in the Retail Payments Market

20 Monetary Policy Regime Change and Regional Inflation Dynamics: Looking through the Lens of Sector-Level Data for Korea

21 Costs of Foreign Capital Flows in Emerging Market Economies: Unexpected Economic Growth and Increased Financial Market Volatility

22 글로벌 금리 정상화와 통화정책 과제: 2015년 한국은행 국제컨퍼런스 결과보고서

23 The Effects of Global Liquidity on Global Imbalances

24 실물경기를 고려한 내재 유동성 측정

25 Deflation and Monetary Policy

26 Macroeconomic Shocks and Dynamics of Labor Markets in Korea

27 Reference Rates and Monetary Policy Effectiveness in Korea

29 An Analysis of Trade Patterns in East Asia and the Effects of the Real Exchange Rate Movements

30 Forecasting Financial Stress Indices in Korea: A Factor Model Approach
서현덕·이정연

강종구 · 임호성

최지영

Jooyong Jun

Chi-Young Choi •

Joo Yong Lee

Roisin O'Sullivan

Kyoungsoo Yoon • Jayoung Kim

한국은행 경제연구원

Marie-Louise DJIGBENOU-KRE •

Hail Park

우준명·이지은

Barry Eichengreen

Tae Bong Kim •

Hangyu Lee

Heung Soon Jung •

Dong Jin Lee.

Tae Hyo Gwon .

Se Jin Yun

Bongseok Choi •

Wooyoung Park.

Bok-Keun Yu

Moon Jung Choi

Geun-Young Kim • Joo Yong Lee

Hyeongwoo Kim $\cdot$ Hyun Hak Kim. Wen Shi 


\begin{tabular}{|c|c|c|}
\hline 제2016 -1 & $\begin{array}{l}\text { The Spillover Effects of U.S. Monetary } \\
\text { Policy on Emerging Market Economies: } \\
\text { Breaks, Asymmetries and Fundamentals }\end{array}$ & $\begin{array}{l}\text { Geun-Young Kim } \cdot \\
\text { Hail Park· } \\
\text { Peter Tillmann }\end{array}$ \\
\hline 2 & $\begin{array}{l}\text { Pass-Through of Imported Input Prices to } \\
\text { Domestic Producer Prices: Evidence from } \\
\text { Sector-Level Data }\end{array}$ & $\begin{array}{l}\text { JaeBin Ahn } \\
\text { Chang-Gui Park } \\
\text { Chanho Park }\end{array}$ \\
\hline 3 & $\begin{array}{l}\text { Spillovers from U.S. Unconventional } \\
\text { Monetary Policy and Its Normalization } \\
\text { to Emerging Markets: A Capital Flow } \\
\text { Perspective }\end{array}$ & $\begin{array}{l}\text { Sangwon Suh } \\
\text { Byung-Soo Koo }\end{array}$ \\
\hline 4 & $\begin{array}{l}\text { Stock Returns and Mutual Fund Flows } \\
\text { in the Korean Financial Market: } \\
\text { A System Approach }\end{array}$ & $\begin{array}{l}\text { Jaebeom Kim } \\
\text { Jung-Min Kim }\end{array}$ \\
\hline 5 & $\begin{array}{l}\text { 정책금리 변동이 성별·세대별 고용률에 } \\
\text { 미치는 영향 }\end{array}$ & 정성엽 \\
\hline 6 & $\begin{array}{l}\text { From Firm-level Imports to } \\
\text { Aggregate Productivity: Evidence } \\
\text { from Korean Manufacturing Firms Data }\end{array}$ & $\begin{array}{l}\text { JaeBin Ahn } \\
\text { Moon Jung Choi }\end{array}$ \\
\hline 7 & $\begin{array}{l}\text { 자유무역협정(FTA)이 한국 기업의 } \\
\text { 기업내 무역에 미친 효과 }\end{array}$ & 전봉걸·김은숙·이주용 \\
\hline 8 & $\begin{array}{l}\text { The Relation Between Monetary and } \\
\text { Macroprudential Policy }\end{array}$ & Jong Ku Kang \\
\hline 9 & $\begin{array}{l}\text { 조세피난처 투자자가 투자 기업 및 주식 } \\
\text { 시장에 미치는 영향 }\end{array}$ & 정호성·김순호 \\
\hline 10 & $\begin{array}{l}\text { 주택실거래 자료를 이용한 주택부문 거시 } \\
\text { 건전성 정책 효과 분석 }\end{array}$ & 정호성·이지은 \\
\hline 11 & $\begin{array}{l}\text { Does Intra-Regional Trade Matter in } \\
\text { Regional Stock Markets?: New Evidence } \\
\text { from Asia-Pacific Region }\end{array}$ & $\begin{array}{l}\text { Sei-Wan Kim } \cdot \\
\text { Moon Jung Choi }\end{array}$ \\
\hline 12 & $\begin{array}{l}\text { Liability, Information, and Anti-fraud } \\
\text { Investment in a Layered Retail } \\
\text { Payment Structure }\end{array}$ & $\begin{array}{l}\text { Kyoung-Soo Yoon } \\
\text { Jooyong Jun }\end{array}$ \\
\hline 13 & $\begin{array}{l}\text { Testing the Labor Market Dualism in } \\
\text { Korea }\end{array}$ & $\begin{array}{l}\text { Sungyup Chung. } \\
\text { Sunyoung Jung }\end{array}$ \\
\hline 14 & $\begin{array}{l}\text { 북한 이중경제 사회계정행렬 추정을 통한 } \\
\text { 비공식부문 분석 }\end{array}$ & 최지영 \\
\hline
\end{tabular}




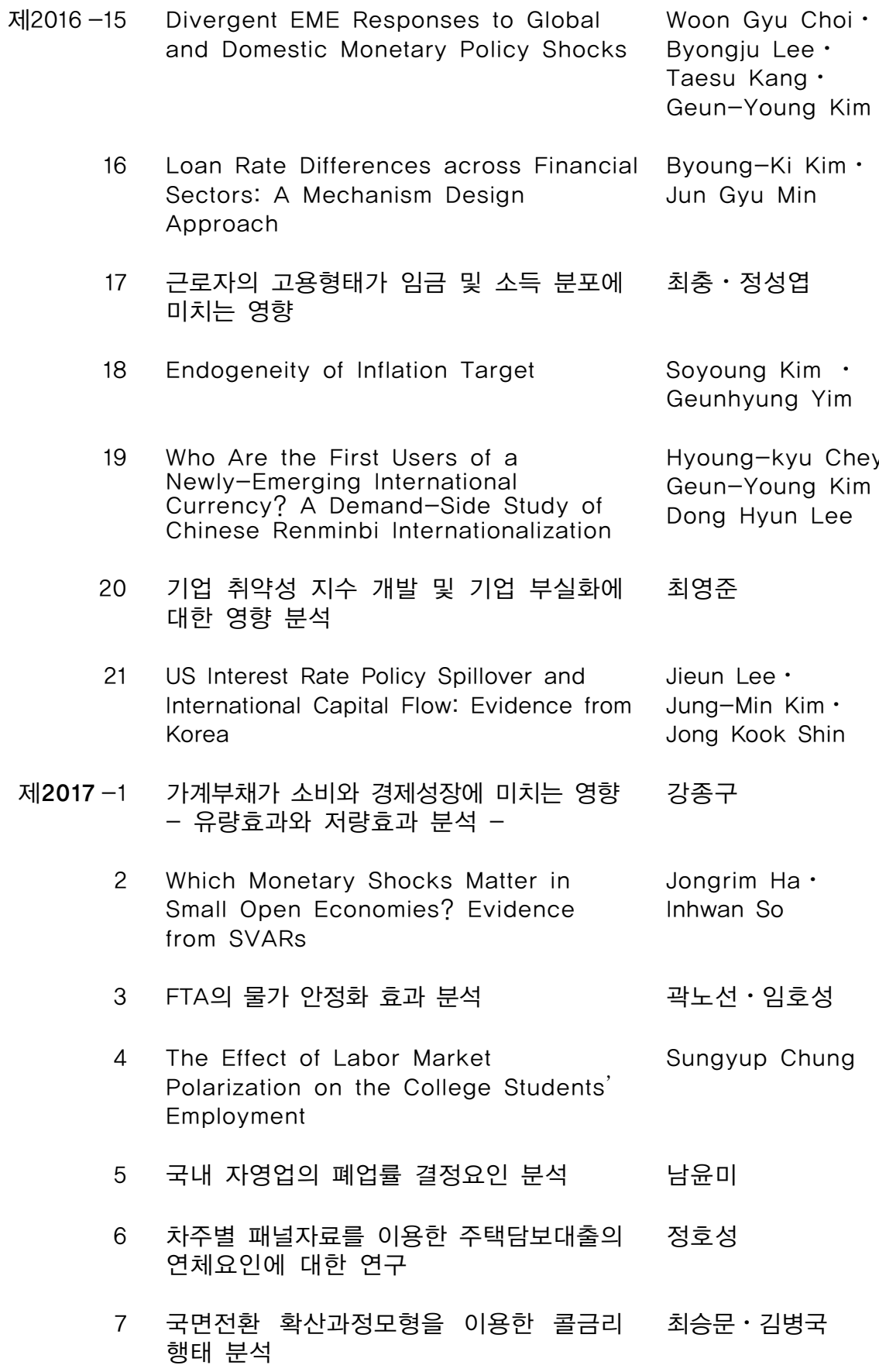

20 기업 취약성 지수 개발 및 기업 부실화에 최영준 대한 영향 분석

21 US Interest Rate Policy Spillover and International Capital Flow: Evidence from Korea

Jieun Lee $\cdot$

Jung-Min Kim •

Jong Kook Shin

제2017-1 가계부채가 소비와 경제성장에 미치는 영향 강종구

- 유량효과와 저량효과 분석 -

2 Which Monetary Shocks Matter in Small Open Economies? Evidence from SVARs

Jongrim $\mathrm{Ha} \cdot$ Inhwan So

3 FTA의 물가 안정화 효과 분석

곽노선·임호성

4 The Effect of Labor Market Polarization on the College Students'

Sungyup Chung Employment

5 국내 자영업의 폐업률 결정요인 분석 남윤미

6 차주별 패널자료를 이용한 주택담보대출의 정호성 연체요인에 대한 연구

7 국면전환 확산과정모형을 이용한 콜금리 최승문·김병국 행태 분석 


\begin{tabular}{|c|c|c|}
\hline 제2017 -8 & $\begin{array}{l}\text { Behavioral Aspects of Household } \\
\text { Portfolio Choice: Effects of Loss } \\
\text { Aversion on Life Insurance Uptake } \\
\text { and Savings }\end{array}$ & In Do Hwang \\
\hline 9 & 신용공급 충격이 재화별 소비에 미치는 영향 & 김광환 · 최석기 \\
\hline 10 & 유가가 손익분기인플레이션에 미치는 영향 & 김진용 - 김준철 - 임형준 \\
\hline 11 & $\begin{array}{l}\text { 인구구조변화가 인플레이션의 장기 추세에 } \\
\text { 미치는 영향 }\end{array}$ & 강환구 \\
\hline 12 & $\begin{array}{l}\text { 종합적 상환여건을 반영한 과다부채 } \\
\text { 가계의 리스크 요인 분석 }\end{array}$ & 이동진·한진현 \\
\hline 13 & $\begin{array}{l}\text { Crowding out in a Dual Currency Regime? } \\
\text { Digital versus Fiat Currency }\end{array}$ & $\begin{array}{l}\text { KiHoon Hong } \cdot \\
\text { Kyounghoon Park } \\
\text { Jongmin } \mathrm{Yu}\end{array}$ \\
\hline 14 & $\begin{array}{l}\text { Improving Forecast Accuracy of } \\
\text { Financial Vulnerability: Partial Least } \\
\text { Squares Factor Model Approach }\end{array}$ & $\begin{array}{l}\text { Hyeongwoo Kim• } \\
\text { Kyunghwan Ko }\end{array}$ \\
\hline 15 & $\begin{array}{l}\text { Which Type of Trust Matters?: } \\
\text { Interpersonal vs. Institutional vs. } \\
\text { Political Trust }\end{array}$ & In Do Hwang \\
\hline 16 & 기업특성에 따른 연령별 고용행태 분석 & 이상욱·권철우·남윤미 \\
\hline 17 & $\begin{array}{l}\text { Equity Market Globalization and } \\
\text { Portfolio Rebalancing }\end{array}$ & $\begin{array}{l}\text { Kyungkeun Kim } \\
\text { Dongwon Lee }\end{array}$ \\
\hline 18 & $\begin{array}{l}\text { The Effect of Market Volatility on } \\
\text { Liquidity and Stock Returns in the } \\
\text { Korean Stock Market }\end{array}$ & Jieun Lee $\cdot \mathrm{KeeH}$.Chung \\
\hline 19 & $\begin{array}{l}\text { Using Cheap Talk to Polarize or Unify } \\
\text { a Group of Decision Makers }\end{array}$ & Daeyoung Jeong \\
\hline 20 & $\begin{array}{l}\text { 패스트트랙 기업회생절차가 법정관리 기업의 } \\
\text { 이자보상비율에 미친 영향 }\end{array}$ & 최영준 \\
\hline 21 & 인구고령화가 경제성장에 미치는 영향 & 안병권·김기호·육승환 \\
\hline 22 & $\begin{array}{l}\text { 고령화에 대응한 인구대책: OECD사례를 중심 } \\
\text { 으로 }\end{array}$ & 김진일·박경훈 \\
\hline
\end{tabular}




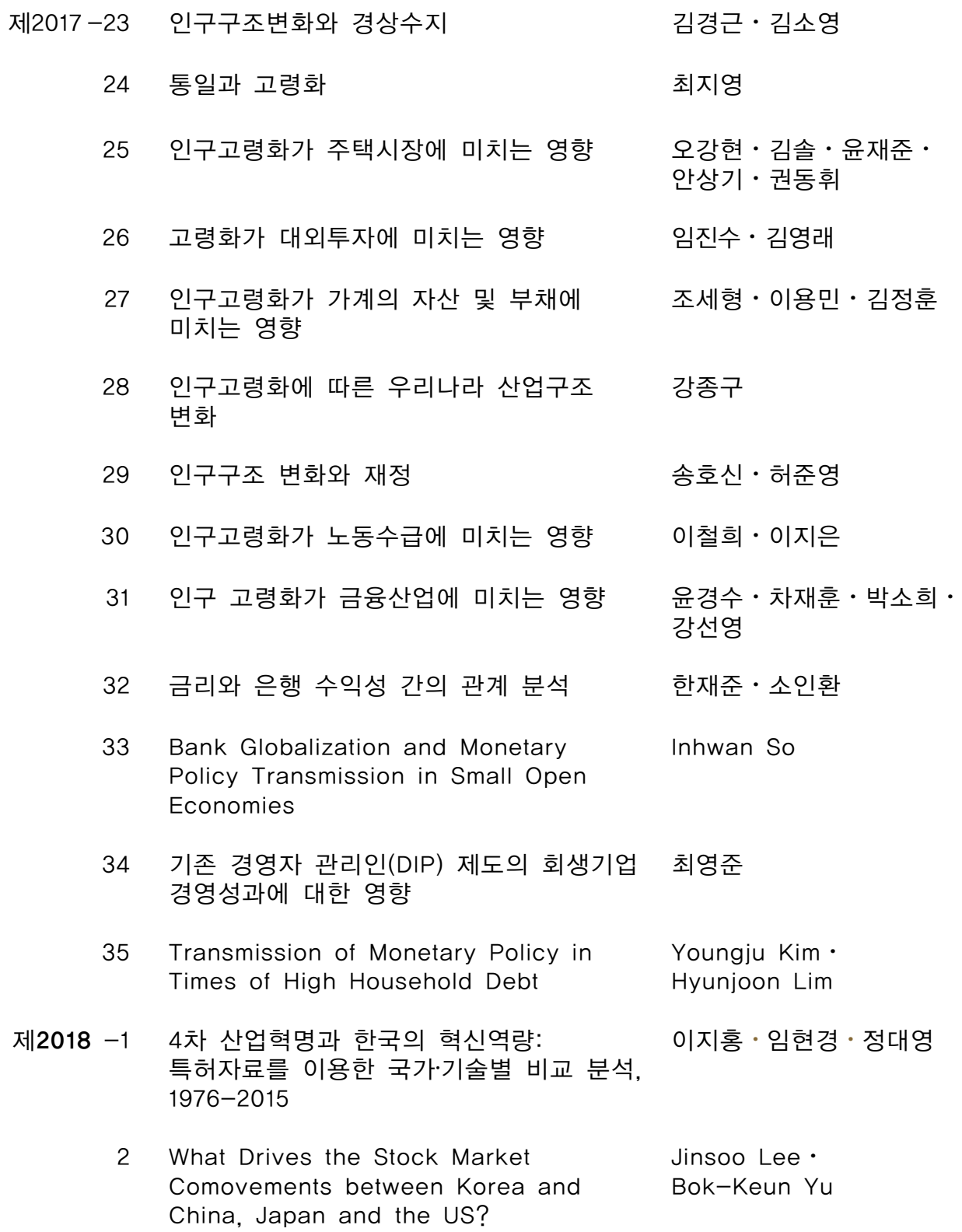

34 기존 경영자 관리인(DIP) 제도의 회생기업 경영성과에 대한 영향

35 Transmission of Monetary Policy in Times of High Household Debt

Youngju Kim • Hyunjoon Lim

제2018 -1 4차 산업혁명과 한국의 혁신역량:

특허자료를 이용한 국가-기술별 비교 분석, 이지홍·임현경·정대영 1976-2015

2 What Drives the Stock Market Comovements between Korea and China, Japan and the US?

Jinsoo Lee Bok-Keun $\mathrm{Yu}$ 